\title{
Immunotherapy in pancreatic cancer-an emerging role: a narrative review
}

\author{
Elena Rangelova ${ }^{1,2}$, Helen Kaipe ${ }^{3,4}$ \\ ${ }^{1}$ Section of Upper Abdominal Surgery at Department of Surgery, Sahlgrenska University Hospital, Gothenburg, Sweden; ${ }^{2}$ Department of Surgery, \\ The Institute of Clinical Sciences, Sahlgrenska Academy, University of Gothenburg, Gothenburg, Sweden; ${ }^{3}$ Department of Laboratory Medicine, \\ Karolinska Institutet, Stockholm, Sweden; ${ }^{4}$ Clinical Immunology and Transfusion Medicine, Karolinska University Hospital, Stockholm, Sweden \\ Contributions: (I) Conception and design: E Rangelova; (II) Administrative support: Both authors; (III) Provision of study materials or patients: E \\ Rangelova; (IV) Collection and assembly of data: E Rangelova; (V) Data analysis and interpretation: Both authors; (VI) Manuscript writing: Both \\ authors; (VII) Final approval of manuscript: Both authors. \\ Correspondence to: Elena Rangelova, MD, PhD, FACS. Department of Upper Abdominal Surgery, Sahlgrenska University Hospital, Blå Stråket 5, \\ Floor 2, 41345 Gothenburg, Sweden. Email: elena.rangelova@gu.se.
}

Background and Objective: Immunotherapy is the fastest growing branch in oncology that have already revolutionized the treatment of few solid cancers. The number of immunotherapy trials for pancreatic cancer (PC) is growing but the vast number of different agents used make it difficult to comprehend a possible success trait of a certain type of immunotherapy. The aim of this review is to summarize and critically evaluate the outcome of immunotherapy trials for PC intended to aid the comprehensiveness for the treating physicians.

Methods: A PubMed search was performed to identify clinical trials in patients with PC, published in English from year 2000 to June 2021 and using combination of the terms immunotherapy, PC, and crosschecked the bibliography of the revised literature as the dublettes have been removed. Studies were divided into three groups depending on what immune components have been applied: passive products (peptides, antibodies, etc.), antigen-presenting cells, and adoptive cell transfer trials.

Key Content and Findings: The vast majority of trials, including those from most recent years, used passive products of the immune system-peptide vaccines and antibodies. The administration was often parallel to chemotherapy that was prevalently gemcitabine-based. Although immunological responses have been detected, the clinical efficacy was very limited. Trials with check point inhibitors did not show survival advantage. Dendritic cell (DC) vaccines have been associated with some clinical objective response and prolonged survival in few patients with delayed type hypersensitivity reactions. Trials with adoptive transfer therapy are lacking. The very few trials with lymphokine-activated killer (LAK)/cytokine-induced killer (CIK) cells tested only in Asian population have resulted in some clinical effects with prolonged survival. In none of the trials have the patients been preconditioned before receiving immunotherapy.

Conclusions: Although the clinical effectiveness in the majority of the reported trials has been limited, the immunological effects observed in almost all trials show a proof of concept-that immunotherapy can work. Careful re-evaluation of the clinical premises and focus on combination and cell therapy may be the way to achieve improved survival by immunotherapy in PC.

Keywords: Pancreatic cancer (PC); immunotherapy; checkpoint inhibitors; T cell; cancer vaccines

Submitted Dec 14, 2021. Accepted for publication Feb 24, 2022.

doi: $10.21037 / \mathrm{cco}-21-174$

View this article at: https://dx.doi.org/10.21037/cco-21-174 


\section{Introduction}

Pancreatic cancer (PC) is one among very few cancer types for which the prognosis has not improved much over the past decades (1). While the 5 -year survival for all cancers altogether is above $60 \%$, the survival of all-stage PC remains below $10 \%(1,2)$. Three major features of PC make it particularly difficult to treat and roadmap its dismal prognosis. The tricky anatomic location not only predefines the limitation to extend surgical resection margins, resulting in about $80 \% \mathrm{R} 1$ resections, but is also the reason why about $30 \%$ of patients present with locally advanced disease with tumor advancement along major abdominal vessels and propagation along the rich neural routes in the area (2-4). Second, $\mathrm{PC}$ is prone to give early rise of metastases that can occur even before the primary tumor becomes visible to the clinician (5). This is one of the explanations why even smaller primary resectable tumors tend to recur in the majority of cases even following curative resection, leaving a 5 -year chance of survival of only about $20 \%$ (2). These two major characteristics of $\mathrm{PC}$ are the reason why systemic oncologic treatment is making its way as the new standard in the neoadjuvant setting. Its purpose is to combat occult distant spread and/or consolidate the advanced tumor in order to select who would benefit the most from surgical resection. However, as potent and promising the new combination regimens like FOLFIRINOX or gemcitabine-nab-paclitaxel might be in prolonging life, used alone they basically never lead to cure due to the microenvironment architecture of PC.

The third unfortunate characteristic of PC is the abundant stroma that shields the tumors cells and defines its chemoresistance $(6,7)$. The poor vascular tumor network is responsible for the ineffective drug delivery and is the driver of hypoxia which enhances endothelial-mesenchymal transformation and invasiveness of PC cells (8). The thick fibrotic stroma increases the distance between the vessels and the tumor cells and mechanically hampers the diffusion of the infused drugs, which cannot reach the cancer cells in therapeutic concentrations (9). Thus, theoretically any passively infused treatment would be doomed to failure.

The tumor microenvironment also plays an active role in carcinogenesis and tumor progression. The components of the immune system are part of this environment and depending on the immune cell composition and its balance, it can either tip over the response toward tumor antigen recognition and appropriate adoptive anti-tumoral response or aid in escaping effective tumor recognition and elimination. Manipulating the immune response towards continuous activation and tumor recognition is the basis of immunotherapy-the fastest growing branch of oncology. Immunotherapy has already revolutionized the treatment of some dismal cancer types, such as malignant melanoma or lung cancer $(10,11)$. In particular, treatment with check point inhibitors has led to long-term survival in patients with melanoma and renal cancer $(10,12,13)$. Inevitably, there is hope that immunotherapy may have similar significant impact on the prognosis of PC. The theoretical advantage of immunotherapy compared to cytotoxic drugs is that it will not only "work" during the treatment occasion but can perpetuate itself and be able to augment and persist during cancer recognition and elimination.

The purpose of this review is to give a comprehensive overview of the role and current attempts of immunotherapy for PC from the clinician's perspective of possible integration in treatment, to map the problematic areas and to highlight what might be opportunities for successful implementation. We present the following article in accordance with the Narrative Review reporting checklist (available at https://cco. amegroups.com/article/view/10.21037/cco-21-174/rc).

\section{Methods}

A search in PubMed was performed to identify clinical trials in humans, published in English between January 2000 and June 2021 and using components of the immune system for immunomodulation in patients with PC. Search was performed using a combination of the search terms "immunotherapy", "pancreatic cancer", "pancreatic adenocarcinoma", "check-point inhibitors", "vaccine", "peptide vaccine", "antibody", "dendritic cells", "tumor infiltrating lymphocytes", and the bibliography of the revised literature cross-checked for additional references as the dublettes have been removed. Trials in which other products were tested, targeting signaling pathways not directly and specifically targeting the immune system were excluded.

\section{The role of the immune system in PC}

The immune system plays an active part in PC tumorigenesis throughout the stages of cancer immunoediting, from elimination, through equilibrium to the escape phase $(14,15)$. The immune cell populations and immune mediators increase and change progressively as precursor lesions of PC evolve to invasive cancers, aiding the tumor to progress and increase its aggressiveness (16-18). The initial "good" local 
inflammation is represented by players with better effector function such as $\mathrm{CD}^{+}$and Th1 $\mathrm{CD} 4^{+} \mathrm{T}$-lymphocytes, natural killer (NK) cells, mature dendritic cells (DC), type 1 macrophages, IL- 1, TNF- $\alpha$, IFN- $\gamma$. It gradually becomes replaced by "bad" inflammation, sustaining cancer growth. The latter is described by regulatory (Tregs) and ineffective CD $8^{+}$T-lymphocytes, immature DCs, myeloid derived suppressor cells (MDSCs), type 2 macrophages, IL-10, TGF- $\beta(18,19)$. Interestingly, PC cells can mimic suppressive immune features that allow them to modulate the immune response against them. PC cells secrete inhibitory signals such as TGF- $\beta$, IL-10 and IL-6, VEGF, and express PD-L1, Fas-L, co-stimulatory molecules (B7-H3, CD40, CD40L) and can down-regulate the expression of antigens that could reveal their presence (19-21).

The typical for PC stromal reaction arises already during the early PanIN stages of tumor development (8). It not only traps and segregates immune cells from their target cancer cells, but also plays an active part in immunomodulation. $\mathrm{PC}$-associated fibroblasts (CAFs), which represent the major cellular component in the desmoplastic stroma, can reduce $\mathrm{T}$ cell function in the stroma by receptor-mediated mechanism and promote expression of co-inhibitory markers on T cells $(22,23)$. The stroma also recruits immunosuppressive Foxp $3^{+}$ $\mathrm{CD}^{+} \mathrm{T}_{\text {reg }}$ lymphocytes and tumor-associated macrophages (TAMs) (24-26).

Extensive presence of tumor infiltrating lymphocytes (TILs) in cancerous lesions has been associated with improved survival in different cancer types (26-33). $\mathrm{T}$ cells are practically lacking in normal pancreas but increase in precancerous lesions and invasive cancer with grossly varying density of infiltration. A few studies point out that higher tumoral infiltration with TILs in resected pancreatic specimen, particularly by $\mathrm{CD}^{+}$TILs, is associated with 5 -survival as high as $42 \%$ (31). Coinfiltration by various populations of $\mathrm{CD}^{+}, \mathrm{CD}^{+}$TILs and DCs, perhaps reflecting better crosstalk in antigenpresentation and immune recognition resulted in a survival of $48 \%$ in 5 years (31).

In contrast to for instance colorectal cancer, TILs in PC do not have a distinct distribution to center and periphery of the tumor but have a more patchy appearance $(26,27,29)$. Whether stromal or intraepithelial TILs are more important is also uncertain $(29,30,32) . \mathrm{CD}^{+}$and CD8 ${ }^{+}$TILs have been observed captured in the stromal tissue, far away from cancer cells and lacking the expression marker of memory cells, CD45RO (34). While some of the $\mathrm{CD} 8^{+}$TILs population may still be naïve $\left(\mathrm{CD} 45 \mathrm{RB}^{\text {high }}\right.$,
CD $44^{\text {low }}$ ) as shown in mice models (17), others would have recognized a tumor antigen (35), meaning that under favorable conditions these are likely to be reacting against the cancer components that express them.

Better patient survival has been reported when high infiltration of $\mathrm{CD}^{+} \mathrm{PD}-1^{+}$TILs was present, suggesting that PD-1, besides being an inhibitory marker, could also represent experienced and activated TILs recognizing a tumor target $(26,36)$. PD-1 expression is also a possible predictive marker for success for eventual check-point inhibitor (CPI) therapy (26).

\section{Immunotherapy for PC}

Immunotherapy has been particularly successful in tumors with high-mutational load, such as malignant melanoma (37). This phenomenon provides plenty of epitopes for the immune system to target and is associated with the presence effector immune cells. Thus, the probability that any of the tumor antigens will be crucial for the cancer propagation and may induce a strong response is higher. $\mathrm{PC}$ is a cancer with low mutational load-in the range of 30-60 mutations compared to over 500 in melanoma $(37,38)$. Also, with its poorer infiltration with effector $\mathrm{T}$ lymphocytes there are fewer potential "responders" to any immune-modulating signals. The addition of the abundant tumoral stromal reaction may hamper the delivery of any immune-stimulating drugs and the premises for success of immunotherapy in PC applied by the principles of standard oncologic treatment delivery are limited (38).

Immunotherapy runs better chances for success whenever lower tumor load is present and thus the counteractive effect of the tumor environment is lesser. Phase I and II clinical trials, just like for other types of oncologic therapy, are usually designed for patients with advanced disease who failed previous therapy attempts or are running out of therapeutic options. For cancers like PC, having already worse premises for response to immunotherapy, starting therapy too late may be particularly unlucky and predetermined to failure. Immunotherapy may also need some time to "work", since it targets the mediator (the immune system) rather than the cancer cells directly. An example for this phenomenon is the observation of pseudoprogression in some patients with melanoma treated with CPIs (39). While increase in tumor size may occur during the first weeks of treatment as a result of the beneficial inflammation that takes place, 


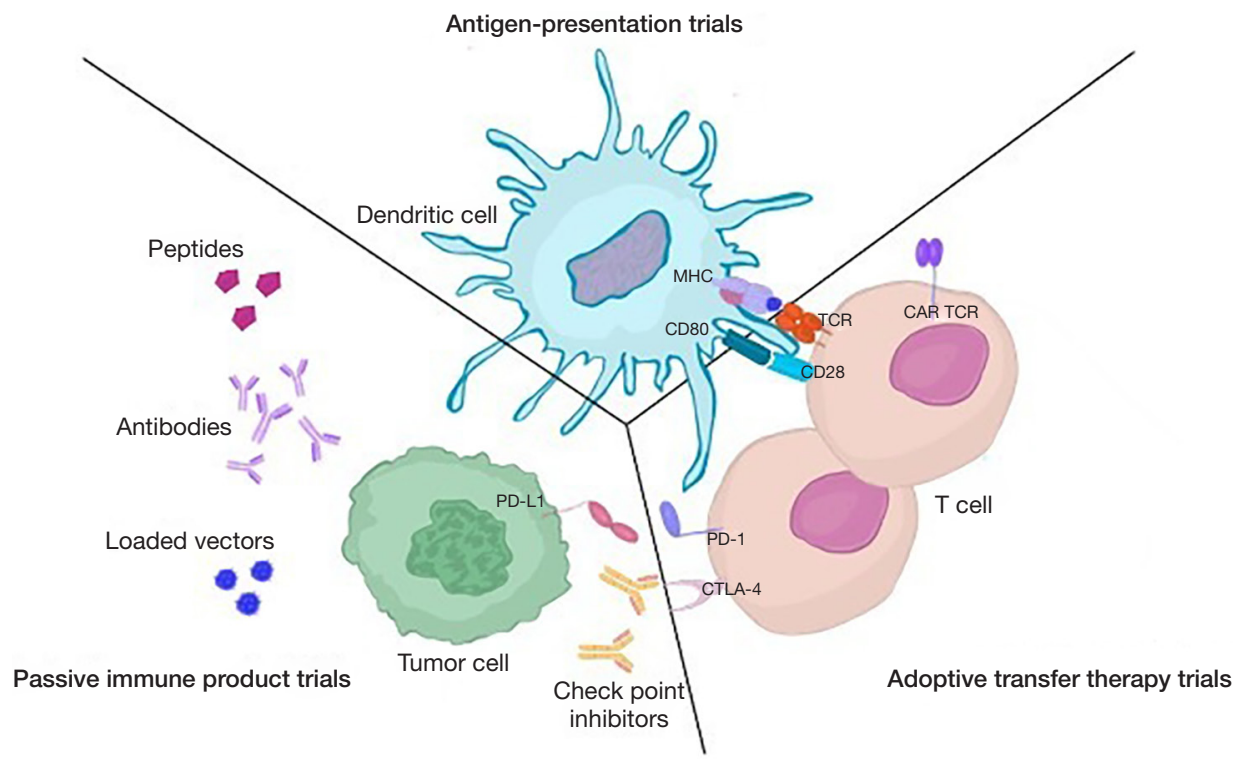

Figure 1 Type of immunotherapy trials in pancreatic cancer.

the real effect becomes obvious within a few months (40). The life expectancy of patients with PC with no treatment option is hardly that long. Although 3 months of expected survival is generally the minimum required to enter a trial, for PC patients with spread disease that is generally an overestimation (41). Fast and sudden deterioration towards lethal outcome is not unusual and may further compromise the planned delivery of treatment cycles.

\section{Immunotherapy trials in PC}

Immunotherapy may provide a variety of different options for treatment based on the parts of the immune response that are being modulated. Loaning principles from the pharmaceutical treatment, the best cost-effective result would be achieved by standardized industrially produced medication, designed to address a certain cancer target. Cancer biology, though, is characterized by complex network of mutations (not unusually private) and changes in signaling pathways that evolve during cancer progression (42). Thus, defining the target that has a central role in the particular person's tumor might be tricky and hitting only one target would mostly probably not be enough to combat the tumor. Applying a combination of drugs is quite often used in immunotherapy trials to both hit a target and to amplify the provoked response.

In order to better summarize and make a more comprehensive evaluation of the different types of immunotherapy studies in PC, we subdivided them into groups, based on what parts of the immune system have been used (Figure 1): (I) passive products of the immune system (tumor antigens, antibodies, interleukins)—secreted products that rely on triggering the whole chain of the immune response; (II) enhanced antigen presentation via the mediators of the immune response-DC; (III) adoptive cell transfer-reinfusion of expanded and activated effector lymphocytes-T-cells, NK cells.

\section{Passive products of the immune system}

Peptides and antibodies are the cheapest the easiest to obtain of the immunotherapy products and they have been most widely tested. They are both readily available and not cumbersome to standardize as pharmacological products. Peptides represent epitopes of a known tumor-associated antigen intended to trigger and boost the immune response against malignant cells. Antibodies are intended for receptor-mediated modulation of a signaling pathway or directly addressing immune cells. What is relied on in both cases is to unlock an effective chain of reactions, which requires the presence and adequate behavior of the other components of the adoptive response-antigen-presenting cells and $\mathrm{T}$ lymphocytes. The latter, though, are heavily influenced by the tumor environment. 


\section{Antigen vaccines}

Boosting the reactivity of the immune system to the tumor cells by repeated exposure to foreign (cancer) antigens is the oldest concept of immunotherapy. Since cancer is derived from the own tissues and therefore prone to induce immunotolerance, tumor-associated antigens that are not present on normal cells can potentially induce immune cell reactivity. Mutations that are obliquitous in $\mathrm{PC}$ are most often the target of interest, such as KRAS, MUC1, survivin (43-55). Completed studies on antigen-based vaccines are summarized in Table 1.

\section{Peptide vaccines}

Peptide vaccines are usually administered with an adjuvant to help enhance their efficacy. They have the advantages of being easy to apply, unexpensive, and can be combined uncomplicatedly with other treatments. They are also usually well tolerated and with few side effects, usually limited to local reaction at the application site. Measurable immunologic reactions as response to their application have been registered in pretty much all trials. However, their effectiveness is limited. Clinical benefit has been observed in single cases and a near complete response has been presented in a case report (49). The exceptionally few trials making it to phase III, however, show no survival benefit from the peptide vaccination $(56,58,64,67)$. For this reason, the interest towards peptide vaccines has been declining over the past years to being almost abandoned. Even in the adjuvant setting after resection, no impressive effect has been observed. Palmer et al. reported survival after resection and vaccination with seven KRAS peptides comparable to that of the patients receiving adjuvant gemcitabine, yet no control arm was present in this study (43). Also, the new current standards for adjuvant treatment with combination chemotherapy give superior results. As a proof of principle, though, immunologic response towards the vaccination agent has been induced in at least part of the patients. Some of the studies also reported a tendency for improved survival in the patients with well-developed immunologic responses (45,55-57,59,71).

\section{Whole tumor vaccines}

Another way of providing antigen stimuli is whole-tumor vaccines. They have the advantages over peptide vaccines that the cells express multiple relevant antigens. Also, the specific antigens do not have to be identified. Particularly the allogenic tumor cell lines are readily available.
Most of the trials have used GVAX, consisting of two allogenic tumor cell lines, tested both in resected and metastatic patients with evidence of immunoreactivity (Table 1). Le et al. reported that when mesothelin-expressing Listeria monocytogenes was added to a combination of GVAX with the immunomodulating chemotherapeutic cyclophosphamide, it almost doubled the survival of patients with metastatic $\mathrm{PC}$ after previous treatment failure-9.7 versus 4.6 months if treated per protocol $(\mathrm{P}=0.02)(77)$. Particularly, enhanced mesothelin-specific $\mathrm{CD} 8^{+} \mathrm{T}$ cell responses have been linked to longer survival. In a following phase IIb RCT, however, the triple combination did not show advantage over physician's choice of single-agent chemotherapy (79). Improved survival after resection for PC have also been observed with GVAX, with a one-year survival of $93 \%$ (73). Another trial tested autologous PC stem cells in phase I but did not report survival data (78). Injection was even attempted towards lymph node groups following resection, with a median survival of 24.8 monthscomparable to standard treatment (75). So far, there are no phase III trials with this type of vaccines.

\section{Vector vaccines}

A few studies aimed to enhance the antigen presentation through vector delivery-virus or attenuated bacteria (77,80-85). The vector may lead to better engagement of innate immune signals by co-stimulation and providing "danger signals" that could more effectively trigger DCs and the following cascade of $\mathrm{T}$ cell activation by the chosen targets such as CEA, KRAS MUC-1, etc. $(80,81,84)$. A couple of studies have aimed at introducing oncolytic viruses locally. Although some trends towards improved survival among the responders in phase I trials $(80,81)$ no benefit has been confirmed in phase II $(84,85)$.

\section{Antibody trials}

Trials using antibodies have marked a peak of publication over the most recent years. Antibodies are a ready product of the immune system that can be industrially produced. The treatment protocols can be standardized as for any other pharmaceutical drug and that translates correspondingly into more straight-forward safety regulation and mass production. In this way clinical trials with antibodies are easier to convey, which explains their domination among the immunotherapy studies for PC for the last couple of years.

The most aimed targets by antibodies in PC are EGFR 


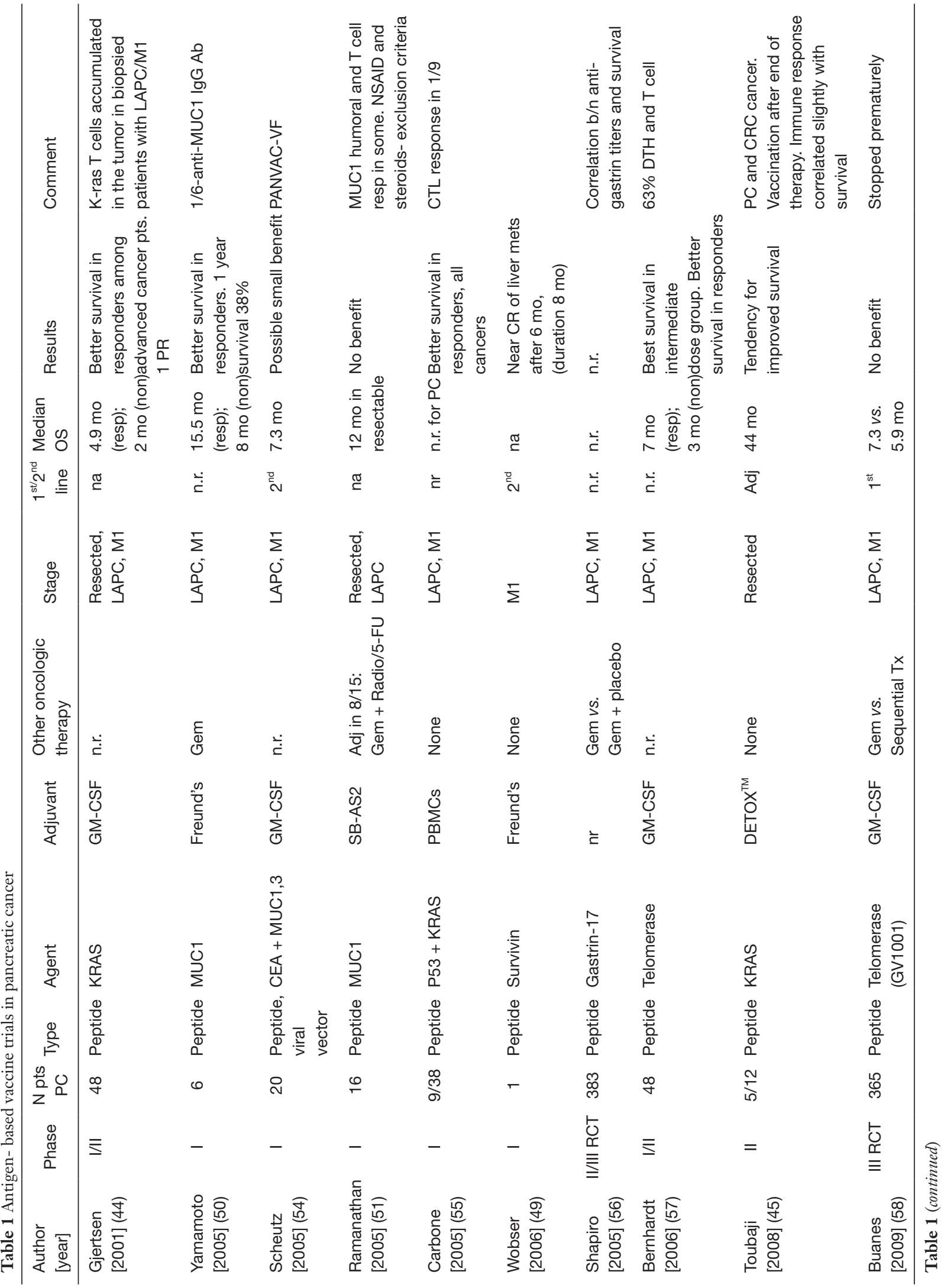




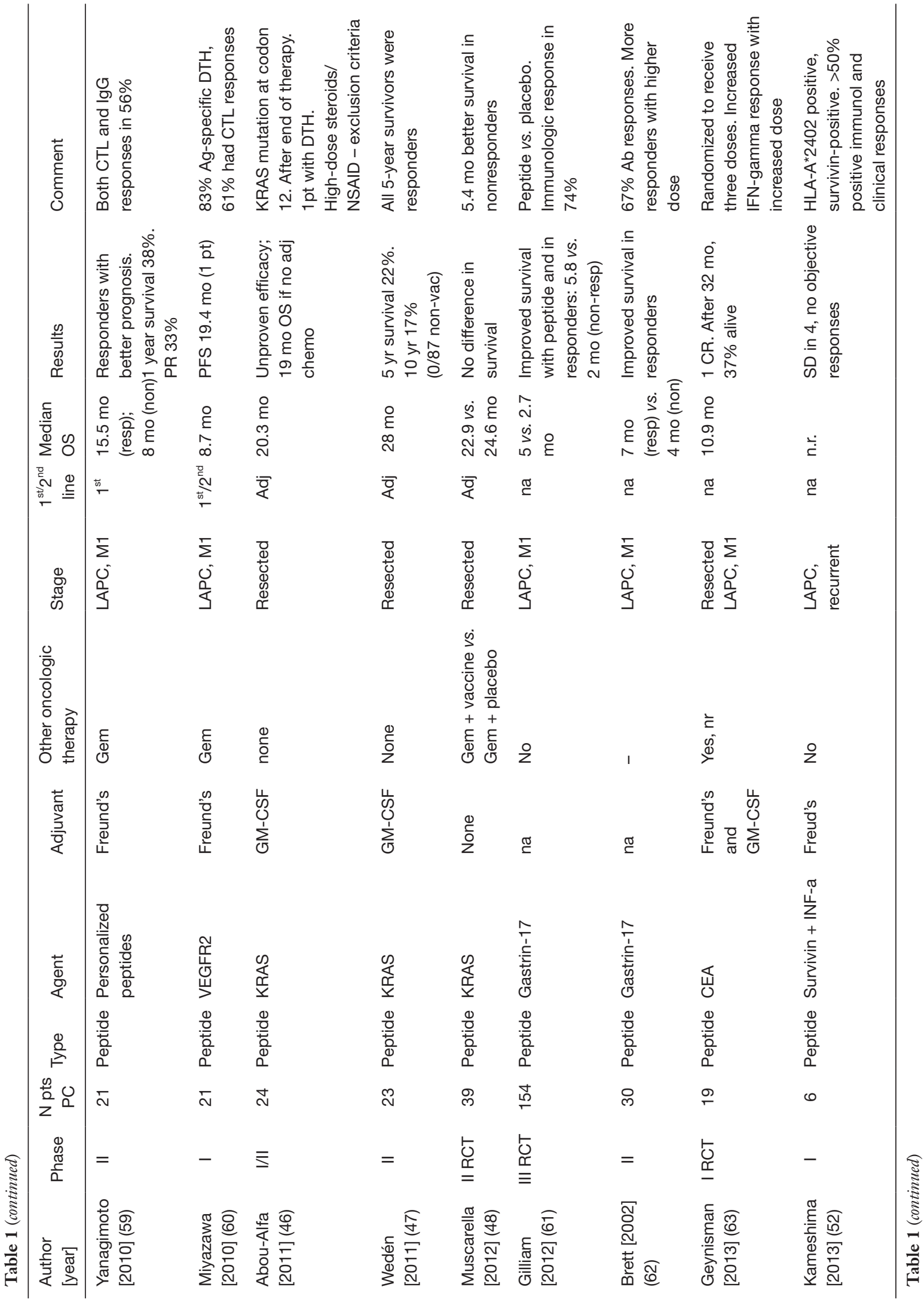




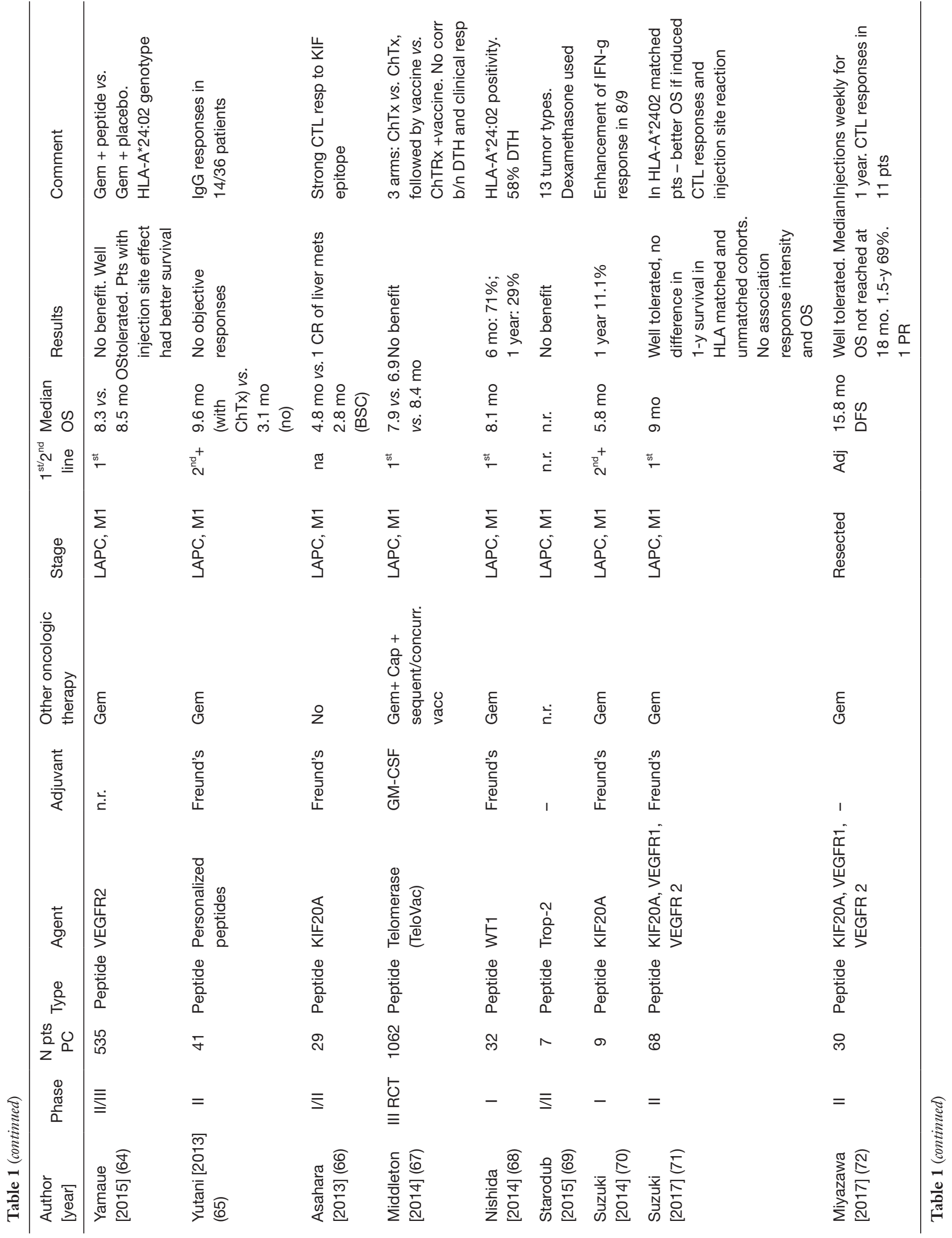




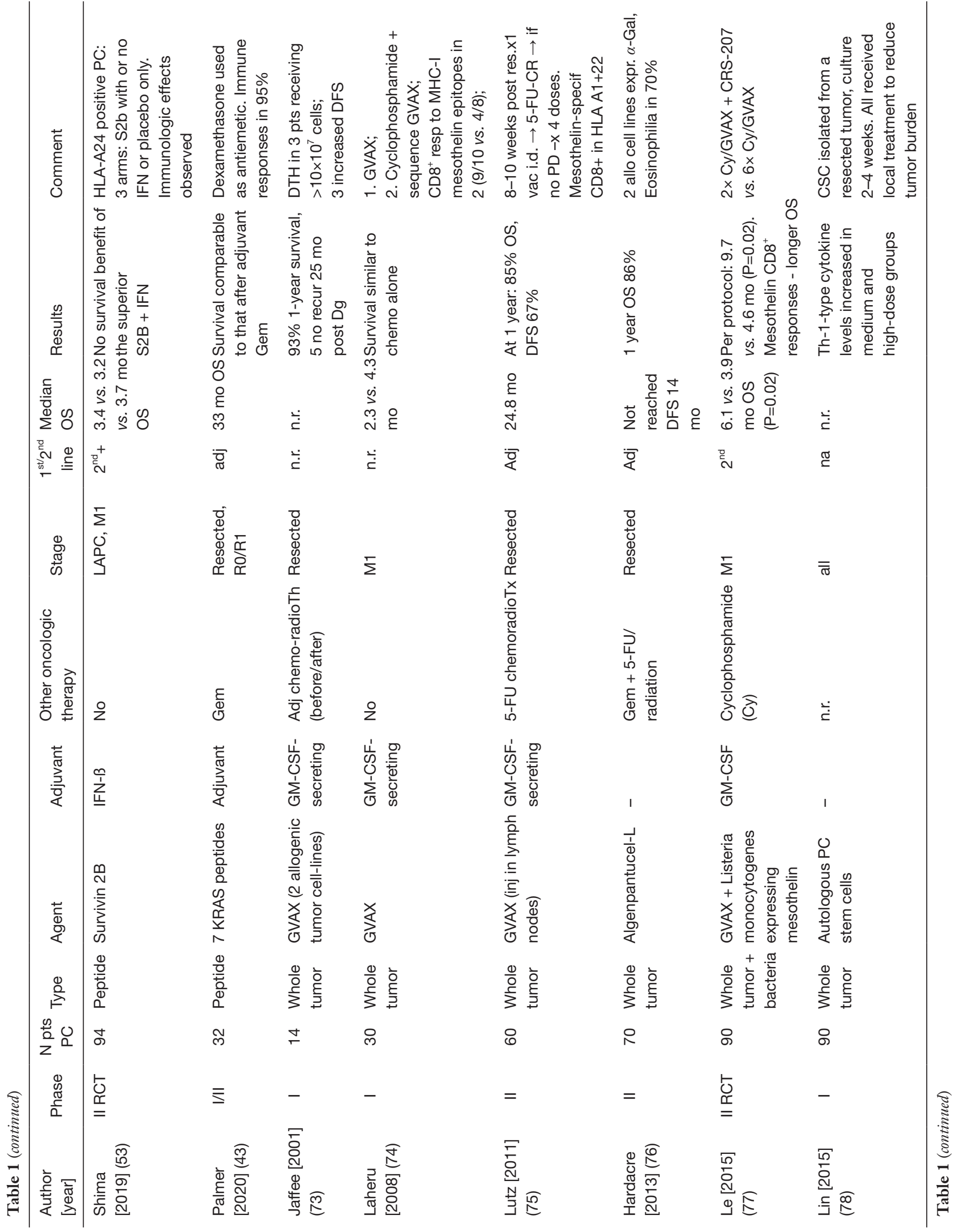




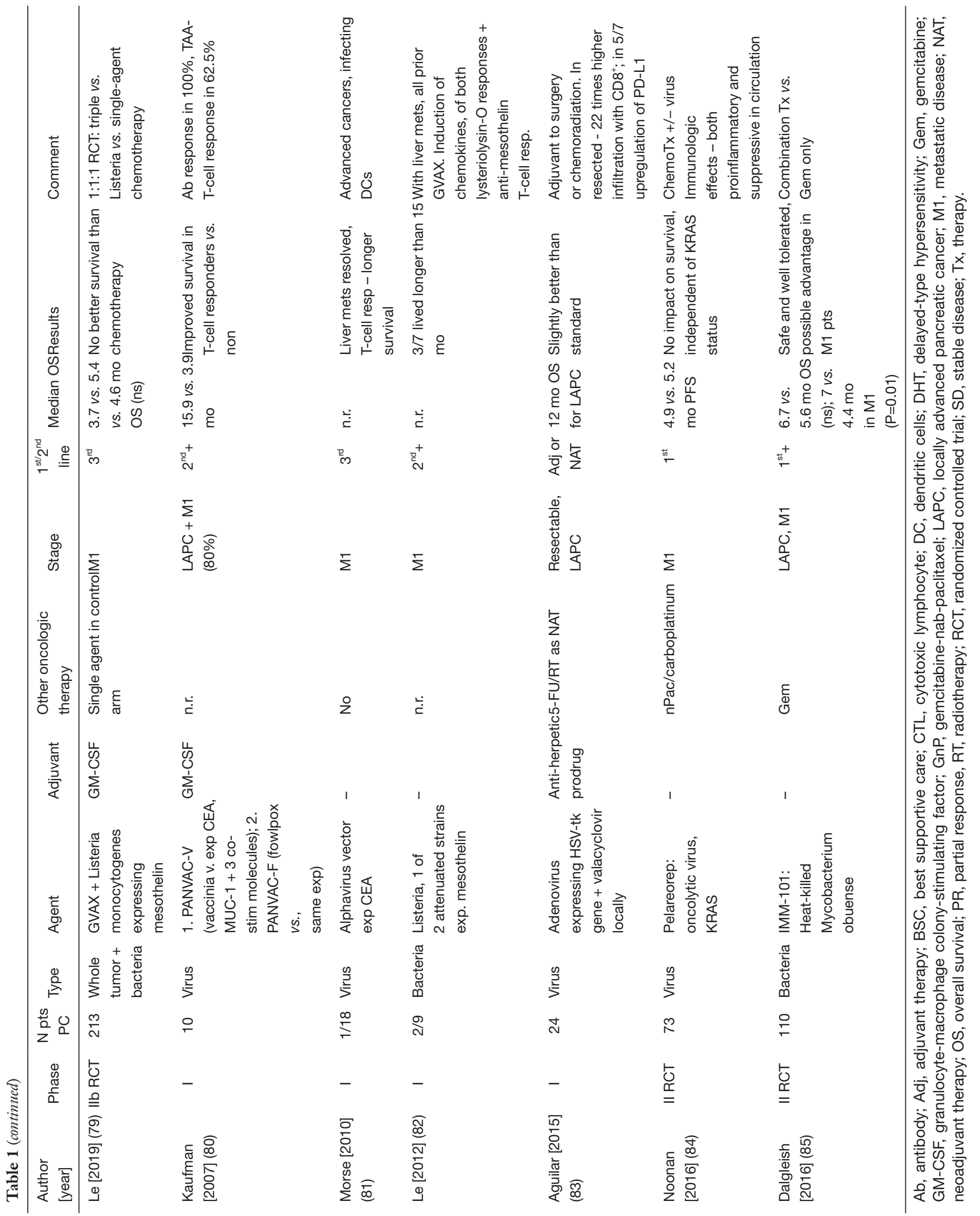


and VEGF-A, which is likely due to that these antibody drugs have already been registered for treatment of other cancer types (Table S1). Whether administered alone or in combination with other targeted drugs or chemotherapy in advanced PC, so far, no improved survival has been seen in phase II and III antibody trials targeting EGFR and VEGF-A, even if applied as first-line therapy (86-91). The few combination trials with more than one of these target agents show some potential survival benefit, but have limited application due to increased toxicity $(92,93)$. No benefit has been seen if antibody treatment has been used in conjunction to surgical resection, either (94-96). Phase II and III trials using different antibodies such as ganitumab, selumetinib, ibrutinib, tarextumab towards IGF1R, MEK, BTK, Notch2/3R (97-100) have failed to show improved survival, as well. Even targeting components of the tumor stroma, such as matrix metalloproteinase-9, have shown no convincing benefit (101).

As earlier studies have shown no benefit of solely antibody therapy, the more recent trials have focused on combination of antibody and chemotherapy. Gemcitabine has been almost exceptionally used, sometimes in combination with nab-paclitaxel (100-102). Gemcitabine has been by far surpassed by FOLFIRINOX in improving survival of patients with advanced PC, yet it is the most tolerable chemotherapeutic available. The toxicity profile of the antibody treatment, however, might restrict its coapplication with the potent chemotherapy and it will be difficult to outrun its efficacy.

\section{Checkpoint inhibitors}

CPIs are a particular group of drugs, mostly antibodies, that deserve special attention. CPI treatment has become the label of practical immunotherapy as they have drastically improved the prognosis of cancers like malignant melanoma where standard treatment has failed (12). CPI block the inhibitory signals on effector $\mathrm{T}$ cells, such as PD-1 and CTLA-4, which are upregulated on T cells to avoid destructive immune overreaction and as a result of exhaustion in the tumor microenvironment. PD-L1 is often expressed on tumor cells and can via ligation with PD-1 on $\mathrm{T}$ cells directly inhibit $\mathrm{T}$ cell function. CTLA-4 provides an inhibitory signal to $\mathrm{T}$ cells after binding to the B7-1 and B7-2 on APC which hence prevents efficient $T$ cell priming and activation.

Unlike the fantastic results that have been achieved in other cancer types, so far CPI have not proved to be particularly effective in trials with patients having advanced
PC, with or without concomitant chemotherapy (Table 2). The reported survival has generally been no better than using single gemcitabine (121). One study reported acceptable tolerability of pembrolizumab used in the neoadjuvant setting for resectable and borderline resectable PC, but provided no survival data (110). The resectability rate was slightly higher in the CPI group-71\% versus $50 \%$, however, the groups were too small to allow for any conclusions. A study from China in cases with only local recurrence found improved survival by 2 months if CPI was used instead of gemcitabine in conjunction to radiation therapy (128).

Interestingly, a link has been reported between defective mismatch repair genes (dMMR) and response to PD-1 and PD-L1 inhibitors $(117,129)$. In a retrospective cohort, one complete and one partial response have been seen in 7 patients receiving CPI and having dMMR, which is considerably better response rate than what all other studies have reported (117). Unfortunately, the presence of $\mathrm{dMMR}$ is a very rare event in patients with PC-only in $0.8 \%$ (129). Generally, CPI do not seem to have any ground-breaking effect in patients with advanced PC.

\section{DC vaccines}

The idea of using DCs in cancer vaccines follows the initial trials of antigen vaccination in an attempt to improve the immunoreactivity by correct major histocompatibility complex (MHC)-restricted antigen presentation to the effector lymphocytes and providing additional costimulation. This type of antigen presentation is a potent inductor of effector $\mathrm{CD}^{+}$and $\mathrm{CD} 8^{+}$lymphocytes.

In $\mathrm{PC}, \mathrm{DC}$ vaccination is in many cases combined with cellular therapy-lymphokine-activated killer cells (LAK) or cytokine-induced killer cells (CIK) (Table 3). In the trials with vaccination with DCs only, the latter have been pulsed with peptides $(130,132,136,139-141)$ or mRNA (135). In patients with advanced cancer, no objective responses have generally been observed $(130,136,139,140)$. Some authors report isolated cases where partial (131) or no tumor activity was observed after longer follow up (135). Inducing specific delayed-type hypersensitivity responses by DC vaccines has been associated with improved survival (139). Interestingly, when DCs have been applied in the adjuvant setting after resection for PC, $100 \%$ of the patients survived the first year (132).

The studies combining DC vaccination with LAK cells or CIK have all been conducted in Asian population 


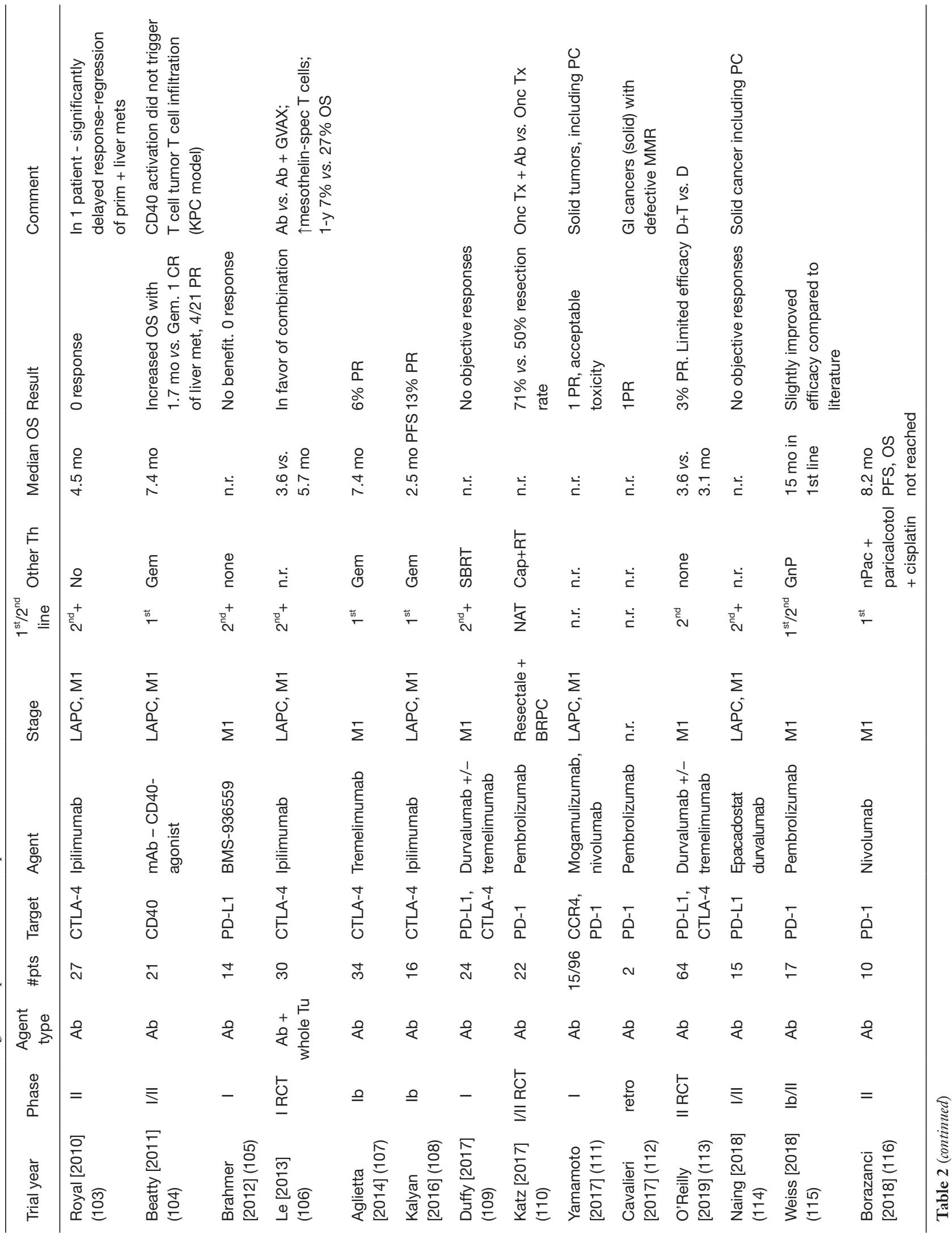




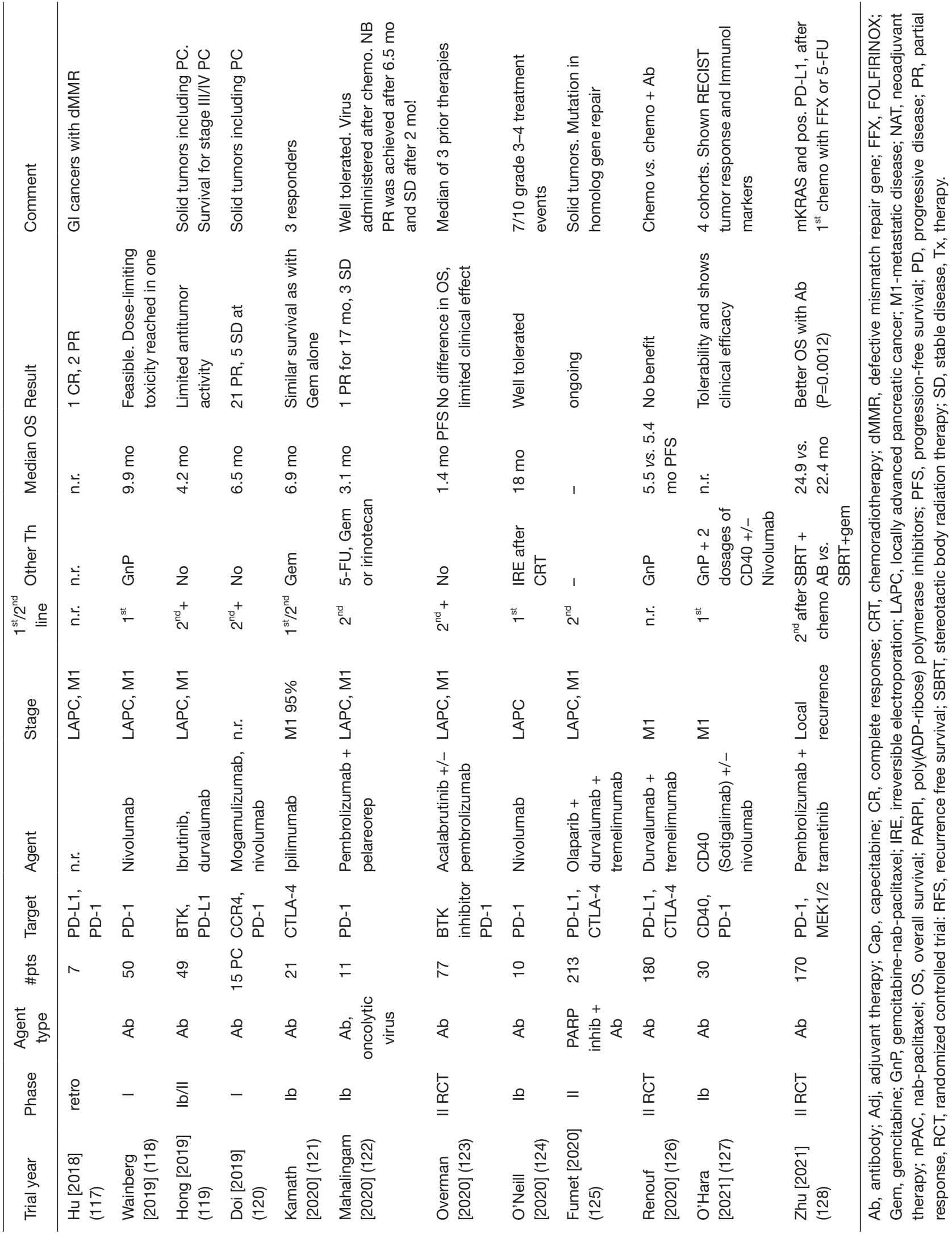




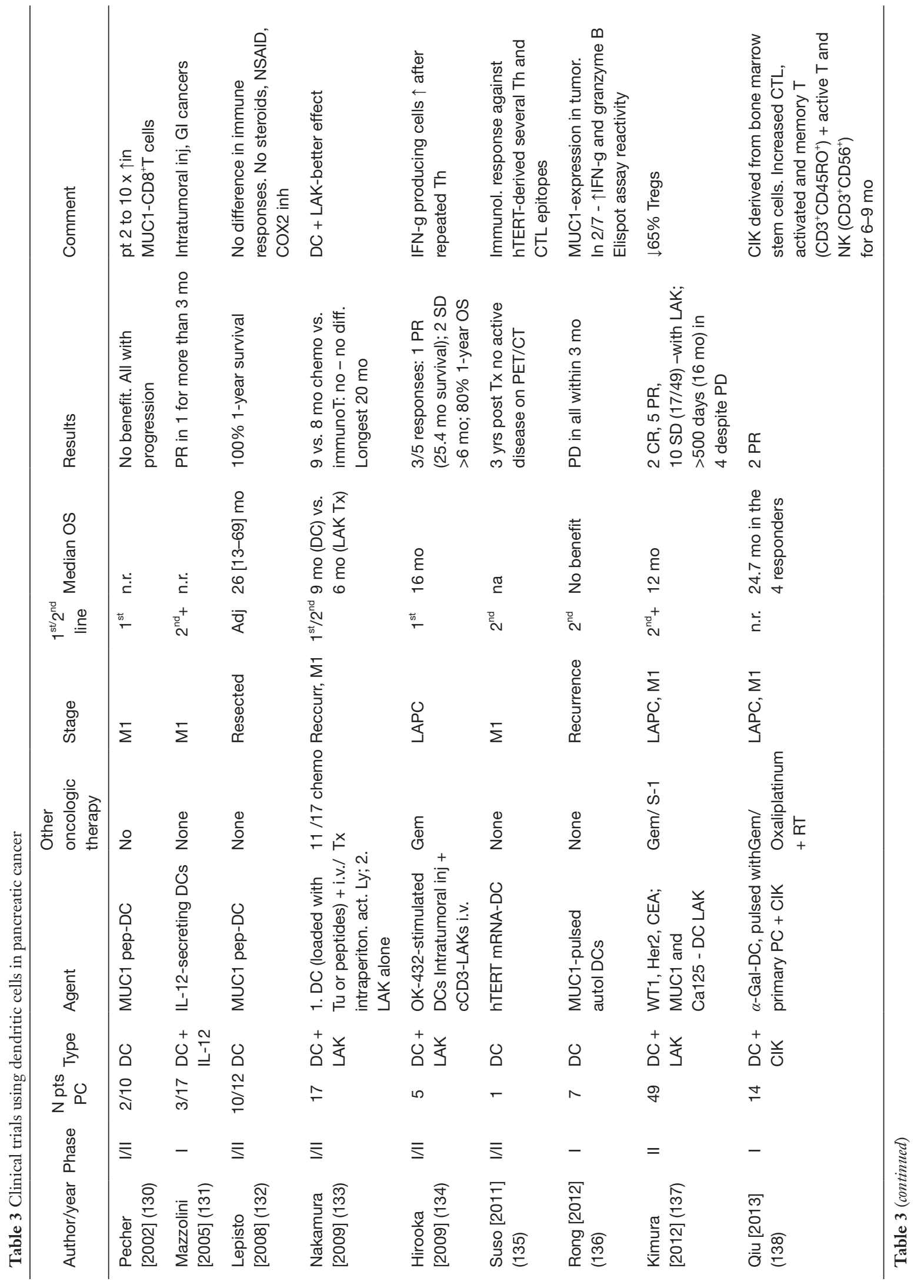




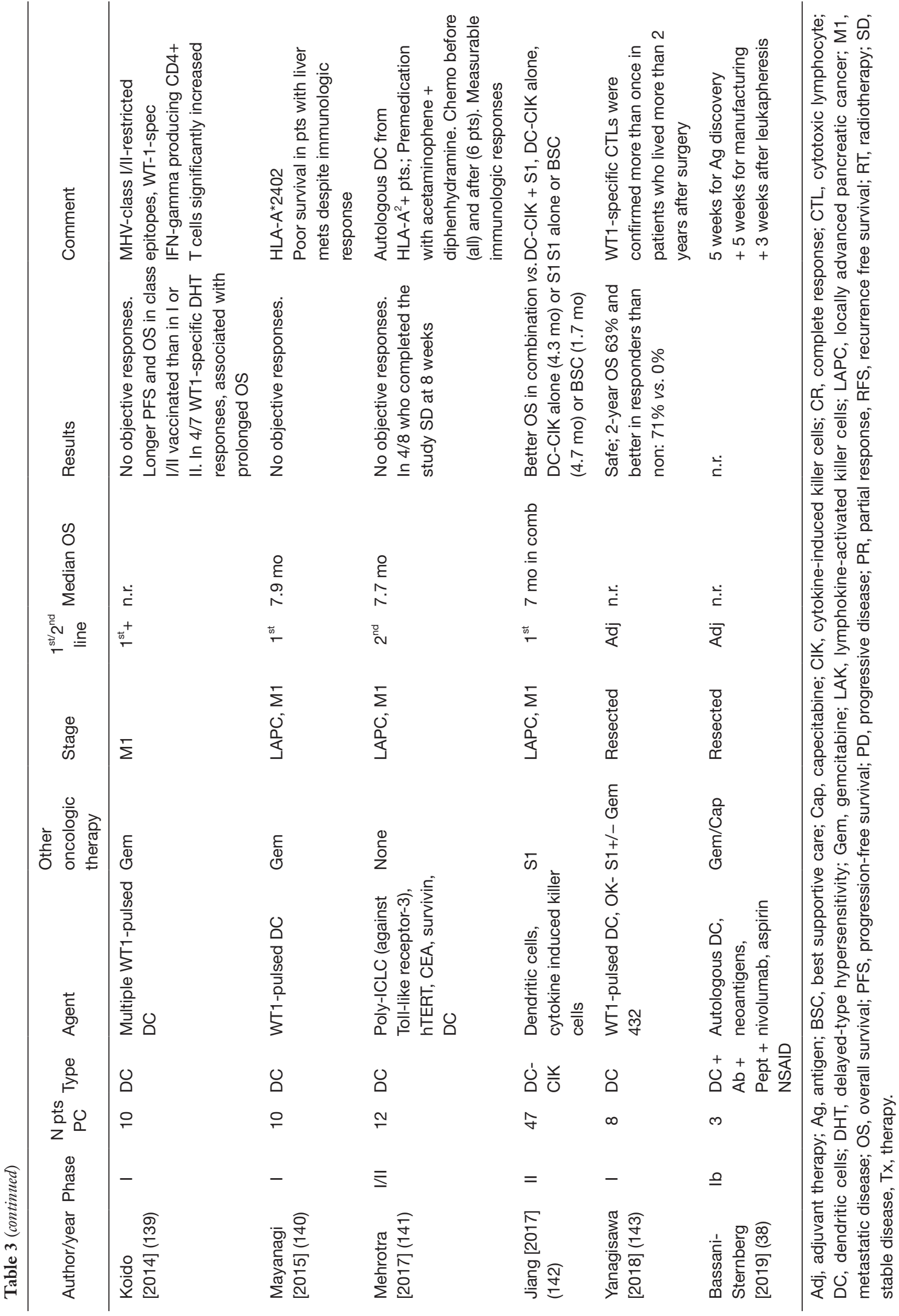


$(133,134,137,142)$. Unlike the isolated DC vaccination, in these trials some objective responses were observed. Kimura et al. reported objective responses in $34 \%$ of the treated patients out of which two were complete responses (137). Hirooka et al. reported a median survival of 16 months and a 1-year survival of $80 \%$ in five patients with LAPC where DC were injected in the tumor while LAK were given intravenously-a result that can hardly be explained by the gemcitabine monotherapy that was used (134). However, larger studies are lacking.

\section{Cellular therapy}

The most efficient form of immunotherapy reported to date is adoptive cell transfer therapy using TILs $(144,145)$. In patients with metastatic malignant melanoma, objective responses have been observed in $72 \%$ when TILs were administered after pre-conditioning chemotherapy with cyclophosphamide and fludarabine and whole-body radiation $(144,146)$. In the patients who were found to be complete responders (impressive $22 \%$ of patients), the 3 and 5 -year survival was $100 \%$ and $93 \%$, respectively. A later randomized trial showed that these results can be achieved without radiation (147). Such results have not been achieved by any other type of oncologic therapy. The isolation of TILs, however, is a cumbersome process and has for long been impossible in PC. It was first reported by our group in 2016 that TILs from PC can be isolated using a cytokine cocktail of IL-2, IL-15, and IL-21 and expanded in sufficient amount to be sufficient for therapy (148). Another group also reported the isolation of TILs (149). So far, the data is only preclinical, but clinical trials are ongoing $(150,151)$.

The most used immune cells for therapy are LAK cells and CIK and in combination with DC vaccination, as descried in the previous section (Table 3). Qiu et al. used autologous CIK together with pulsed DCs and reported a median survival of 24.7 months among the four responders with advanced PC (Table 3) (138). Chung et al reported that $60 \%$ of patients with metastatic PC were alive after 6 months after treatment with autologous CIK and not receiving any other oncologic treatment (Table 4) (154).

T cell therapy has also been attempted in PC, with cells derived from peripheral blood mononuclear cells (PBMCs) but without any overwhelming efficacy. Both allogeneic and autologous T lymphocytes from PBMCs sensitized to MUC-1 have been tested in resected and advanced PC $(152,153)$. The combination of $\mathrm{T}$ cell and DCs has resulted in one out of 20 patients with advanced cancer with complete response, alive after 6 years (153). $\gamma \delta \mathrm{T}$ cells retrieved and applied after resection have not proved to be of survival advantage (155). CAR-T cells for mesothelin have been tested in metastatic PC and two out of six patients have shown stable disease for 3.8 and 5.4 months without any other ongoing therapy (157). A common feature of all $\mathrm{T}$ cell trials is that, unlike the experience from TIL therapy, no preceding lymphodepleting treatment have been administered.

An interesting study has reported the use of allogeneic hematopoietic stem cell transplantation from HLAidentical siblings in patients with PC, analogical to its use in hematologic disease (158). Two patients receiving the treatment after radical resection for PC were both still alive after 9 years. Both cellular and humoral reactivity against two novel tumoral antigens has been observed as evidence for immunologically mediated treatment effect against cancer. Of course, larger trials are necessary before any conclusions can be drawn.

\section{Discussion}

As PC is constantly the one that fails to respond to any treatment attempts by standard oncologic means, inevitably lots of hope is brought onto immunotherapy to stop this closed cycle of desperation. The immunotherapy trials in PC have so far not shown a large-scale impact on prognosis in a broad patient cohort. Even though the clinical effects of immunotherapy have been limited, the immunological changes induced in response to treatment indicate a proof of concept-immunotherapy works. The premises for success, though, need to be diligently reevaluated.

Apparently, immunotherapy planned and delivered just like chemotherapy does not work in PC. Yet, the vast majority of the most recent trials seek to evaluate the potential efficacy of the mass-produced standardized antibody medication to an unselected cohort of patients. While CPI treatment would work in melanoma where the premises with mobilizing the infiltrating TILs, which recognize a large number of mutations, are already present in the tumors, in PC with its much fewer, scattered, and often naive, TILs, that strategy as a single treatment option seems to be meaningless. If CPI might work in combination, for example with a stroma-targeting drug in order to aid accessibility of CPI to cancer cells in PC is unknown. However, it is the cheapest and most profitable type of treatment. But what could be the roadmap to immunotherapy's success in PC? 


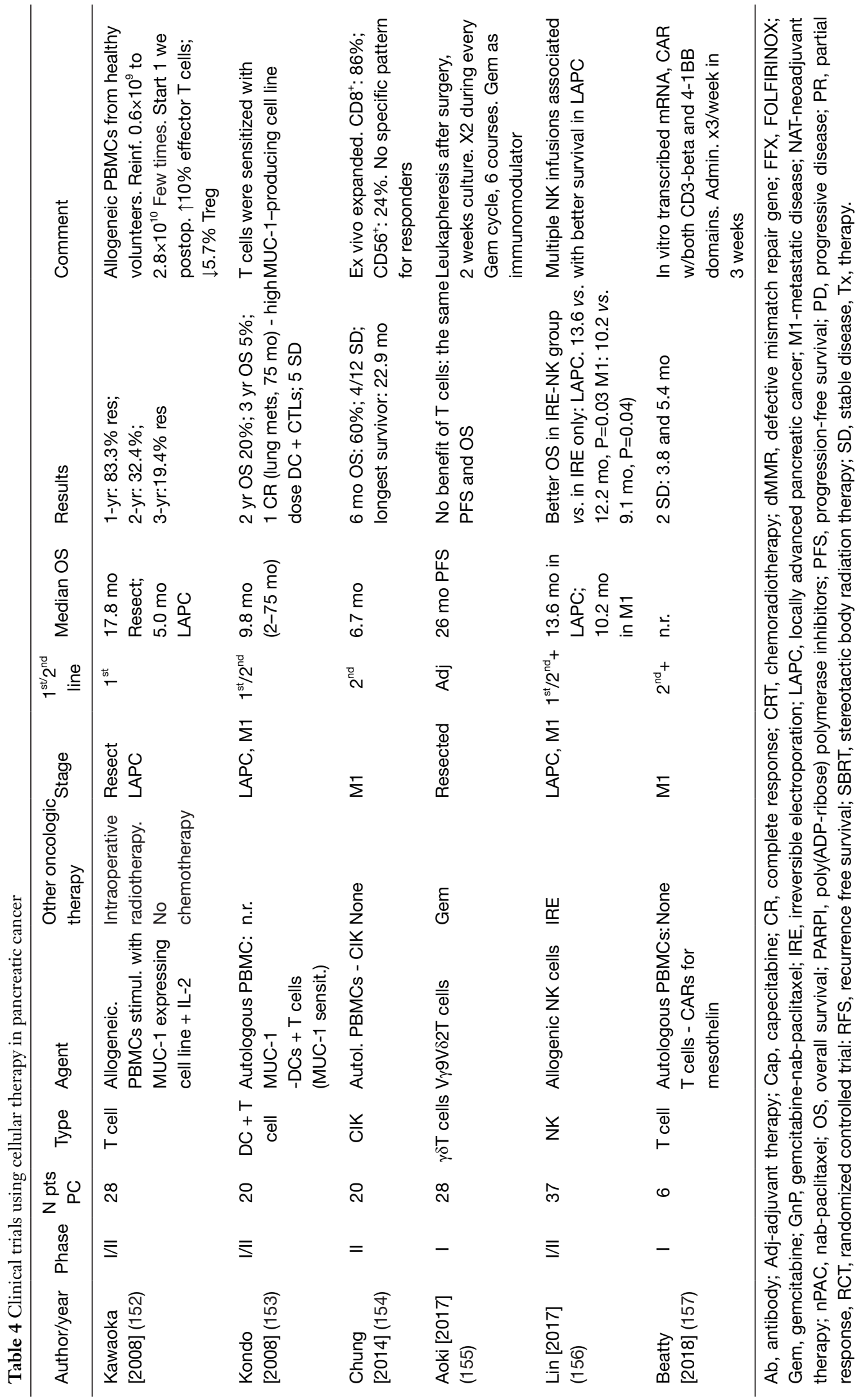


PC has from baseline a lower probability of success with immunotherapy. Theoretically, adoptive transfer therapy with ex vivo expanded effector $\mathrm{T}$ lymphocytes would be the most appropriate choice to address the problem of having fewer mutations and fewer TILs. This means that the mutational profile of the individual patients' tumors, carrying quite often private mutations, needs to be outlined - by genetic sequencing and typing of the T-cell receptors of the TILs. Apparently, this is a very costly undertaking that universities must cover, since for the industry that option is unattractive. This is a major limitation of this type of treatment. Using cellular therapy against preselected tumor associated antigen (TAAs), that has been tried so far, is not even nearly effective.

Immunotherapy by itself is among the most precise and strictly targeted treatments.

Cancers have evolved in a variety of molecular mechanisms to evade the recognition by the immune system. A combined strategy, by addressing a few of these mechanisms rather than picking a single target, should result in better efficacy. For example, an autopsy investigation after a vaccine trial revealed that the tumors of patients have been largely infiltrated by lymphocytes (159). Yet, this has not been enough to change the outcome, since the tumors have been overexpressing PD-L1. Supposedly, combination with a CPI might have improved the outcome. Combination strategies are, though, much more difficult to plan, since there are a variety of parameters to control forchoice and sequence of administration of the components, dosages, timing during treatment, etc.

The right timing and route of administration during the individual treatment algorithm of each patient is another point of concern. Complementation to surgical resection would hypothetically be the best scenario as the tumor burden has been reduced the most and the mutational landscape of the whole tumor can be assessed. The generation of a good product for adoptive transfer therapy, is a time-restricted process in order to generate the most efficient young TILs (160-162). This means that reinfusion would need to be two to three weeks after surgery, but this is perhaps the most inconvenient period in terms of healing and complications. Pancreatic surgery is inevitably associated with up to $40-50 \%$ complications rate and the development of pancreatic fistula or deconditioning may hamper the process. Longer culture of the TILs may drive them to exhaustion and decrease their effectiveness. On the contrary, a patient with metastatic PC who have progressed upon previous treatment, may deteriorate fast before the immune product has been generated and thus become unsuitable for the protocol. Therefore, adaptation of the planned studies to the clinical scenarios with earlier introduction of immunotherapy, as combination in firstline palliative or neoadjuvant therapy might be worth considering.

Another critical point is the preparation of the patient before treatment. As the autopsy studies after vaccination and the earlier trials in TIL therapy in melanoma revealed, the immunosuppressive environment created and maintained by the tumor rapidly deactivates the administered boosting immune product $(146,159)$. The key to success has been the proper preconditioning by lymphodepletion using cyclophosphamide and fludarabine in order to "create space" for the activated product to settle $(146,147)$. None of the finished trials in PC has used this principle, except for a couple of them relying on the mild and largely insufficient effect of cyclophosphamide or gemcitabine $(141,155)$. Furthermore, chemotherapy that is used in parallel in the prevailing number of immunotherapy studies in PC, often goes with the administration of potent corticosteroids to counteract adverse events $(43,69,163)$. That might theoretically completely deactivate the "good" inflammation that immunotherapy pursues. The route of administration should also be carefully considered. The usual intravenous infusion (apart from DC vaccination) may lead to that a large part of the product is sequestrated when bypassing the pulmonary circulation and does not reach a more distant target in significant amount.

Despite the difficult start, immunotherapy is slowly making its way in the treatment of PC. With careful consideration of the clinical premises, choice of the immune agents and preconditioning, immunotherapy could make a treatment breakthrough in PC.

\section{Summary}

Current studies, mostly using passive immunotherapy with antibodies (including checkpoint inhibitors) and antigen vaccines, have so far not marked a major breakthrough in the treatment of patients with advanced PC. The induced immunologic responses and individual cases of success among responders show a proof of concept-that immunotherapy is an emerging option for the treatment of patients with PC. Careful planning of the studies considering the particular characteristics and premises in patients with PC might be the key to better outcome in the near future. 


\section{Acknowledgments}

Funding: None.

\section{Footnote}

Provenance and Peer Review: This article was commissioned by the Guest Editor (Savio George Barreto) for the series "Unresolved Issues in Pancreatic Cancer" published in Chinese Clinical Oncology. The article has undergone external peer review.

Reporting Checklist: The authors have completed the Narrative Review reporting checklist. Available at https:// cco.amegroups.com/article/view/10.21037/cco-21-174/rc

Conflicts of Interest: Both authors have completed the ICMJE uniform disclosure form (available at https://cco. amegroups.com/article/view/10.21037/cco-21-174/coif). The series "Unresolved Issues in Pancreatic Cancer" was commissioned by the editorial office without any funding or sponsorship. The authors have no other conflicts of interest to declare.

Ethical Statement: The authors are accountable for all aspects of the work in ensuring that questions related to the accuracy or integrity of any part of the work are appropriately investigated and resolved.

Open Access Statement: This is an Open Access article distributed in accordance with the Creative Commons Attribution-NonCommercial-NoDerivs 4.0 International License (CC BY-NC-ND 4.0), which permits the noncommercial replication and distribution of the article with the strict proviso that no changes or edits are made and the original work is properly cited (including links to both the formal publication through the relevant DOI and the license). See: https://creativecommons.org/licenses/by-nc-nd/4.0/.

\section{References}

1. Institute NC. Cancer Stat Facts: Pancreatic Cancer 2020 Available online: www.seer.cancer.gov

2. Socialstyrelsen. Cancer i siffror: populärvetenskapliga fakta om cancer. 2018.

3. Verbeke CS, Leitch D, Menon KV, et al. Redefining the $\mathrm{R} 1$ resection in pancreatic cancer. Br J Surg 2006;93:1232-7.
4. van Roessel S, Kasumova GG, Verheij J, et al. International Validation of the Eighth Edition of the American Joint Committee on Cancer (AJCC) TNM Staging System in Patients With Resected Pancreatic Cancer. JAMA Surg 2018;153:e183617.

5. Rhim AD, Mirek ET, Aiello NM, et al. EMT and dissemination precede pancreatic tumor formation. Cell 2012;148:349-61.

6. Johnson JI, Decker S, Zaharevitz D, et al. Relationships between drug activity in NCI preclinical in vitro and in vivo models and early clinical trials. Br J Cancer 2001;84:1424-31.

7. Halbrook CJ, Pontious C, Kovalenko I, et al. MacrophageReleased Pyrimidines Inhibit Gemcitabine Therapy in Pancreatic Cancer. Cell Metab 2019;29:1390-1399.e6.

8. Feig C, Gopinathan A, Neesse A, et al. The pancreas cancer microenvironment. Clin Cancer Res 2012;18:4266-76.

9. Olive KP, Jacobetz MA, Davidson CJ, et al. Inhibition of Hedgehog signaling enhances delivery of chemotherapy in a mouse model of pancreatic cancer. Science 2009;324:1457-61.

10. Buchanan T, Amouzegar A, Luke JJ. Next-Generation Immunotherapy Approaches in Melanoma. Curr Oncol Rep 2021;23:116.

11. Hsu ML, Naidoo J. Principles of Immunotherapy in Non-Small Cell Lung Cancer. Thorac Surg Clin 2020;30:187-98.

12. Robert C, Schachter J, Long GV, et al. Pembrolizumab versus Ipilimumab in Advanced Melanoma. N Engl J Med 2015;372:2521-32.

13. Iacovelli R, Ciccarese C, Schutz FA, et al. Complete response to immune checkpoint inhibitors-based therapy in advanced renal cell carcinoma patients. A meta-analysis of randomized clinical trials. Urol Oncol 2020;38:798.e17-24.

14. Protti MP, De Monte L. Cross-talk within the tumor microenvironment mediates Th2-type inflammation in pancreatic cancer. Oncoimmunology 2012;1:89-91.

15. Dunn GP, Old LJ, Schreiber RD. The three Es of cancer immunoediting. Annu Rev Immunol 2004;22:329-60.

16. Lesina M, Wörmann SM, Neuhöfer P, et al. Interleukin-6 in inflammatory and malignant diseases of the pancreas. Semin Immunol 2014;26:80-7.

17. Clark CE, Hingorani SR, Mick R, et al. Dynamics of the immune reaction to pancreatic cancer from inception to invasion. Cancer Res 2007;67:9518-27.

18. Evans A, Costello E. The role of inflammatory cells in 
fostering pancreatic cancer cell growth and invasion. Front Physiol 2012;3:270.

19. Sideras K, Braat H, Kwekkeboom J, et al. Role of the immune system in pancreatic cancer progression and immune modulating treatment strategies. Cancer Treat Rev 2014;40:513-22.

20. Loos M, Hedderich DM, Ottenhausen M, et al. Expression of the costimulatory molecule $\mathrm{B} 7-\mathrm{H} 3$ is associated with prolonged survival in human pancreatic cancer. BMC Cancer 2009;9:463.

21. Yamato I, Sho M, Nomi T, et al. Clinical importance of B7-H3 expression in human pancreatic cancer. Br J Cancer 2009;101:1709-16.

22. Gorchs L, Fernández Moro C, Bankhead P, et al. Human Pancreatic Carcinoma-Associated Fibroblasts Promote Expression of Co-inhibitory Markers on CD4+ and CD8+ T-Cells. Front Immunol 2019;10:847.

23. Kleeff J, Korc M, Apte M, et al. Pancreatic cancer. Nat Rev Dis Primers 2016;2:16022.

24. Jiang Y, Du Z, Yang F, et al. FOXP3+ lymphocyte density in pancreatic cancer correlates with lymph node metastasis. PLoS One 2014;9:e106741.

25. Wang X, Luo G, Zhang K, et al. Hypoxic TumorDerived Exosomal miR-301a Mediates M2 Macrophage Polarization via PTEN/PI3K $\gamma$ to Promote Pancreatic Cancer Metastasis. Cancer Res 2018;78:4586-98.

26. Diana A, Wang LM, D'Costa Z, et al. Prognostic value, localization and correlation of PD-1/PD-L1, CD8 and FOXP3 with the desmoplastic stroma in pancreatic ductal adenocarcinoma. Oncotarget 2016;7:40992-1004.

27. Jamieson NB, Mohamed M, Oien KA, et al. The relationship between tumor inflammatory cell infiltrate and outcome in patients with pancreatic ductal adenocarcinoma. Ann Surg Oncol 2012;19:3581-90.

28. Mahajan UM, Langhoff E, Goni E, et al. Immune Cell and Stromal Signature Associated With ProgressionFree Survival of Patients With Resected Pancreatic Ductal Adenocarcinoma. Gastroenterology 2018;155:1625-1639.e2.

29. Miksch RC, Schoenberg MB, Weniger M, et al. Prognostic Impact of Tumor-Infiltrating Lymphocytes and Neutrophils on Survival of Patients with Upfront Resection of Pancreatic Cancer. Cancers (Basel) 2019;11:39.

30. Lohneis P, Sinn M, Bischoff S, et al. Cytotoxic tumourinfiltrating $\mathrm{T}$ lymphocytes influence outcome in resected pancreatic ductal adenocarcinoma. Eur J Cancer 2017;83:290-301.

31. Fukunaga A, Miyamoto M, Cho Y, et al. CD8+ tumor- infiltrating lymphocytes together with CD4+ tumorinfiltrating lymphocytes and dendritic cells improve the prognosis of patients with pancreatic adenocarcinoma. Pancreas 2004;28:e26-31.

32. Tewari N, Zaitoun AM, Arora A, et al. The presence of tumour-associated lymphocytes confers a good prognosis in pancreatic ductal adenocarcinoma: an immunohistochemical study of tissue microarrays. BMC Cancer 2013;13:436.

33. Ino Y, Yamazaki-Itoh R, Shimada K, et al. Immune cell infiltration as an indicator of the immune microenvironment of pancreatic cancer. Br J Cancer 2013;108:914-23.

34. Ademmer K, Ebert M, Müller-Ostermeyer F, et al. Effector $\mathrm{T}$ lymphocyte subsets in human pancreatic cancer: detection of CD8+CD18+ cells and CD8+CD103+ cells by multi-epitope imaging. Clin Exp Immunol 1998;112:21-6.

35. Meng Q, Valentini D, Rao M, et al. Neoepitope targets of tumour-infiltrating lymphocytes from patients with pancreatic cancer. Br J Cancer 2019;120:97-108.

36. Shibuya KC, Goel VK, Xiong W, et al. Pancreatic ductal adenocarcinoma contains an effector and regulatory immune cell infiltrate that is altered by multimodal neoadjuvant treatment. PLoS One 2014;9:e96565.

37. Alexandrov LB, Nik-Zainal S, Wedge DC, et al. Signatures of mutational processes in human cancer. Nature 2013;500:415-21.

38. Bassani-Sternberg M, Digklia A, Huber F, et al. A Phase Ib Study of the Combination of Personalized Autologous Dendritic Cell Vaccine, Aspirin, and Standard of Care Adjuvant Chemotherapy Followed by Nivolumab for Resected Pancreatic Adenocarcinoma-A Proof of Antigen Discovery Feasibility in Three Patients. Front Immunol 2019;10:1832.

39. Lee JH, Long GV, Menzies AM, et al. Association Between Circulating Tumor DNA and Pseudoprogression in Patients With Metastatic Melanoma Treated With Anti-Programmed Cell Death 1 Antibodies. JAMA Oncol 2018;4:717-21.

40. Hodi FS, Ballinger M, Lyons B, et al. ImmuneModified Response Evaluation Criteria In Solid Tumors (imRECIST): Refining Guidelines to Assess the Clinical Benefit of Cancer Immunotherapy. J Clin Oncol 2018;36:850-8.

41. Haj Mohammad N, Bernards N, Besselink MG, et al. Volume matters in the systemic treatment of metastatic pancreatic cancer: a population-based study in the Netherlands. J Cancer Res Clin Oncol 2016;142:1353-60. 
42. Hanahan D, Weinberg RA. Hallmarks of cancer: the next generation. Cell 2011;144:646-74.

43. Palmer DH, Valle JW, Ma YT, et al. TG01/GM-CSF and adjuvant gemcitabine in patients with resected RASmutant adenocarcinoma of the pancreas (CT TG01-01): a single-arm, phase 1/2 trial. Br J Cancer 2020;122:971-7.

44. Gjertsen MK, Buanes T, Rosseland AR, et al. Intradermal ras peptide vaccination with granulocyte-macrophage colony-stimulating factor as adjuvant: Clinical and immunological responses in patients with pancreatic adenocarcinoma. Int J Cancer 2001;92:441-50.

45. Toubaji A, Achtar M, Provenzano M, et al. Pilot study of mutant ras peptide-based vaccine as an adjuvant treatment in pancreatic and colorectal cancers. Cancer Immunol Immunother 2008;57:1413-20.

46. Abou-Alfa GK, Chapman PB, Feilchenfeldt J, et al. Targeting mutated K-ras in pancreatic adenocarcinoma using an adjuvant vaccine. Am J Clin Oncol 2011;34:321-5.

47. Wedén S, Klemp M, Gladhaug IP, et al. Long-term follow-up of patients with resected pancreatic cancer following vaccination against mutant K-ras. Int J Cancer 2011;128:1120-8.

48. Muscarella P, Bekaii-Saab T, McIntyre K, et al. A Phase 2 Randomized Placebo-Controlled Adjuvant Trial of GI4000, a Recombinant Yeast Expressing Mutated RAS Proteins in Patients with Resected Pancreas Cancer. J Pancreat Cancer 2021;7:8-19.

49. Wobser M, Keikavoussi P, Kunzmann V, et al. Complete remission of liver metastasis of pancreatic cancer under vaccination with a HLA-A2 restricted peptide derived from the universal tumor antigen survivin. Cancer Immunol Immunother 2006;55:1294-8.

50. Yamamoto K, Ueno T, Kawaoka T, et al. MUC1 peptide vaccination in patients with advanced pancreas or biliary tract cancer. Anticancer Res 2005;25:3575-9.

51. Ramanathan RK, Lee KM, McKolanis J, et al. Phase I study of a MUC1 vaccine composed of different doses of MUC1 peptide with SB-AS2 adjuvant in resected and locally advanced pancreatic cancer. Cancer Immunol Immunother 2005;54:254-64.

52. Kameshima H, Tsuruma T, Kutomi G, et al. Immunotherapeutic benefit of $\alpha$-interferon (IFN $\alpha$ ) in survivin2B-derived peptide vaccination for advanced pancreatic cancer patients. Cancer Sci 2013;104:124-9.

53. Shima H, Tsurita G, Wada S, et al. Randomized phase II trial of survivin $2 \mathrm{~B}$ peptide vaccination for patients with HLA-A24-positive pancreatic adenocarcinoma. Cancer Sci 2019;110:2378-85.
54. Schuetz T, Kaufman HL, Marshall JL, et al. Extended survival in second-line pancreatic cancer after therapeutic vaccination. J Clin Oncol 2005;23:184s.

55. Carbone DP, Ciernik IF, Kelley MJ, et al. Immunization with mutant p53- and K-ras-derived peptides in cancer patients: immune response and clinical outcome. J Clin Oncol 2005;23:5099-107.

56. Shapiro J, Marshall J, Karasek P, et al. G17DT+gemcitabine [Gem] versus placebo+Gem in untreated subjects with locally advanced, recurrent, or metastatic adenocarcinoma of the pancreas: Results of a randomized, double-blind, multinational, multicenter study. J Clin Oncol 2005;23::LA4012.

57. Bernhardt SL, Gjertsen MK, Trachsel S, et al. Telomerase peptide vaccination of patients with non-resectable pancreatic cancer: A dose escalating phase I/II study. Br J Cancer 2006;95:1474-82.

58. Buanes T, Maurel J, Liauw W, et al. A randomized phase III study of gemcitabine (G) versus GV1001 in sequential combination with $G$ in patients with unresectable and metastatic pancreatic cancer (PC). J Clin Oncol 2009;27:4601.

59. Yanagimoto H, Shiomi H, Satoi S, et al. A phase II study of personalized peptide vaccination combined with gemcitabine for non-resectable pancreatic cancer patients. Oncol Rep 2010;24:795-801.

60. Miyazawa M, Ohsawa R, Tsunoda T, et al. Phase I clinical trial using peptide vaccine for human vascular endothelial growth factor receptor 2 in combination with gemcitabine for patients with advanced pancreatic cancer. Cancer Sci 2010;101:433-9.

61. Gilliam AD, Broome P, Topuzov EG, et al. An international multicenter randomized controlled trial of G17DT in patients with pancreatic cancer. Pancreas 2012;41:374-9.

62. Brett BT, Smith SC, Bouvier CV, et al. Phase II study of anti-gastrin-17 antibodies, raised to G17DT, in advanced pancreatic cancer. J Clin Oncol 2002;20:4225-31.

63. Geynisman DM, Zha Y, Kunnavakkam R, et al. A randomized pilot phase I study of modified carcinoembryonic antigen (CEA) peptide (CAP1-6D)/ montanide/GM-CSF-vaccine in patients with pancreatic adenocarcinoma. J Immunother Cancer 2013;1:8.

64. Yamaue H, Tsunoda T, Tani M, et al. Randomized phase II/III clinical trial of elpamotide for patients with advanced pancreatic cancer: PEGASUS-PC Study. Cancer Sci 2015;106:883-90.

65. Yutani S, Komatsu N, Yoshitomi M, et al. A phase II study 
of a personalized peptide vaccination for chemotherapyresistant advanced pancreatic cancer patients. Oncol Rep 2013;30:1094-100.

66. Asahara S, Takeda K, Yamao K, et al. Phase I/II clinical trial using HLA-A24-restricted peptide vaccine derived from KIF20A for patients with advanced pancreatic cancer. J Transl Med 2013;11:291.

67. Middleton G, Silcocks P, Cox T, et al. Gemcitabine and capecitabine with or without telomerase peptide vaccine GV1001 in patients with locally advanced or metastatic pancreatic cancer (TeloVac): an open-label, randomised, phase 3 trial. Lancet Oncol 2014;15:829-40.

68. Nishida S, Koido S, Takeda Y, et al. Wilms tumor gene (WT1) peptide-based cancer vaccine combined with gemcitabine for patients with advanced pancreatic cancer. J Immunother 2014;37:105-14.

69. Starodub AN, Ocean AJ, Shah MA, et al. First-in-Human Trial of a Novel Anti-Trop-2 Antibody-SN-38 Conjugate, Sacituzumab Govitecan, for the Treatment of Diverse Metastatic Solid Tumors. Clin Cancer Res 2015;21:3870-8.

70. Suzuki N, Hazama S, Ueno T, et al. A phase I clinical trial of vaccination with KIF20A-derived peptide in combination with gemcitabine for patients with advanced pancreatic cancer. J Immunother 2014;37:36-42.

71. Suzuki N, Hazama S, Iguchi H, et al. Phase II clinical trial of peptide cocktail therapy for patients with advanced pancreatic cancer: VENUS-PC study. Cancer Sci 2017;108:73-80.

72. Miyazawa M, Katsuda M, Maguchi H, et al. Phase II clinical trial using novel peptide cocktail vaccine as a postoperative adjuvant treatment for surgically resected pancreatic cancer patients. Int J Cancer 2017;140:973-82.

73. Jaffee EM, Hruban RH, Biedrzycki B, et al. Novel allogeneic granulocyte-macrophage colony-stimulating factor-secreting tumor vaccine for pancreatic cancer: a phase I trial of safety and immune activation. J Clin Oncol 2001;19:145-56.

74. Laheru D, Lutz E, Burke J, et al. Allogeneic granulocyte macrophage colony-stimulating factor-secreting tumor immunotherapy alone or in sequence with cyclophosphamide for metastatic pancreatic cancer: a pilot study of safety, feasibility, and immune activation. Clin Cancer Res 2008;14:1455-63.

75. Lutz E, Yeo CJ, Lillemoe KD, et al. A lethally irradiated allogeneic granulocyte-macrophage colony stimulating factor-secreting tumor vaccine for pancreatic adenocarcinoma. A Phase II trial of safety, efficacy, and immune activation. Ann Surg 2011;253:328-35.
76. Hardacre JM, Mulcahy M, Small W, et al. Addition of algenpantucel-L immunotherapy to standard adjuvant therapy for pancreatic cancer: a phase 2 study. J Gastrointest Surg 2013;17:94-100; discussion p. 100-1.

77. Le DT, Wang-Gillam A, Picozzi V, et al. Safety and survival with GVAX pancreas prime and Listeria Monocytogenes-expressing mesothelin (CRS-207) boost vaccines for metastatic pancreatic cancer. J Clin Oncol 2015;33:1325-33.

78. Lin M, Yuan YY, Liu SP, et al. Prospective study of the safety and efficacy of a pancreatic cancer stem cell vaccine. J Cancer Res Clin Oncol 2015;141:1827-33.

79. Le DT, Picozzi VJ, Ko AH, et al. Results from a Phase IIb, Randomized, Multicenter Study of GVAX Pancreas and CRS-207 Compared with Chemotherapy in Adults with Previously Treated Metastatic Pancreatic Adenocarcinoma (ECLIPSE Study). Clin Cancer Res 2019;25:5493-502.

80. Kaufman HL, Kim-Schulze S, Manson K, et al. Poxvirusbased vaccine therapy for patients with advanced pancreatic cancer. J Transl Med 2007;5:60.

81. Morse MA, Hobeika AC, Osada T, et al. An alphavirus vector overcomes the presence of neutralizing antibodies and elevated numbers of Tregs to induce immune responses in humans with advanced cancer. J Clin Invest 2010;120:3234-41.

82. Le DT, Brockstedt DG, Nir-Paz R, et al. A live-attenuated Listeria vaccine (ANZ-100) and a live-attenuated Listeria vaccine expressing mesothelin (CRS-207) for advanced cancers: phase I studies of safety and immune induction. Clin Cancer Res 2012;18:858-68.

83. Aguilar LK, Shirley LA, Chung VM, et al. Gene-mediated cytotoxic immunotherapy as adjuvant to surgery or chemoradiation for pancreatic adenocarcinoma. Cancer Immunol Immunother 2015;64:727-36.

84. Noonan AM, Farren MR, Geyer SM, et al. Randomized Phase 2 Trial of the Oncolytic Virus Pelareorep (Reolysin) in Upfront Treatment of Metastatic Pancreatic Adenocarcinoma. Mol Ther 2016;24:1150-8.

85. Dalgleish AG, Stebbing J, Adamson DJ, et al. Randomised, open-label, phase II study of gemcitabine with and without IMM-101 for advanced pancreatic cancer. Br J Cancer 2016;115:e16.

86. Xiong HQ, Rosenberg A, LoBuglio A, et al. Cetuximab, a monoclonal antibody targeting the epidermal growth factor receptor, in combination with gemcitabine for advanced pancreatic cancer: a multicenter phase II Trial. J Clin Oncol 2004;22:2610-6.

87. Van Cutsem E, Vervenne WL, Bennouna J, et al. Phase III 
trial of bevacizumab in combination with gemcitabine and erlotinib in patients with metastatic pancreatic cancer. J Clin Oncol 2009;27:2231-7.

88. Ko AH, Bekaii-Saab T, Van Ziffle J, et al. A Multicenter, Open-Label Phase II Clinical Trial of Combined MEK plus EGFR Inhibition for Chemotherapy-Refractory Advanced Pancreatic Adenocarcinoma. Clin Cancer Res 2016;22:61-8.

89. Fountzilas C, Chhatrala R, Khushalani N, et al. A phase II trial of erlotinib monotherapy in advanced pancreatic cancer as a first- or second-line agent. Cancer Chemother Pharmacol 2017;80:497-505.

90. Abdel-Wahab R, Varadhachary GR, Bhosale PR, et al. Randomized, phase I/II study of gemcitabine plus IGF-1R antagonist (MK-0646) versus gemcitabine plus erlotinib with and without MK-0646 for advanced pancreatic adenocarcinoma. J Hematol Oncol 2018;11:71.

91. Lim SH, Yun J, Lee MY, et al. Gemcitabine and Erlotinib with or without Oxaliplatin in Previously Untreated Advanced Pancreatic Cancer: A Randomized Phase II Trial. Yonsei Med J 2021;62:671-8.

92. Halfdanarson TR, Foster NR, Kim GP, et al. A Phase II Randomized Trial of Panitumumab, Erlotinib, and Gemcitabine Versus Erlotinib and Gemcitabine in Patients with Untreated, Metastatic Pancreatic Adenocarcinoma: North Central Cancer Treatment Group Trial N064B (Alliance). Oncologist 2019;24:589-e160.

93. Mettu NB, Niedzwiecki D, Rushing C, et al. A phase I study of gemcitabine + dasatinib (gd) or gemcitabine + dasat inib + cetuximab (GDC) in refractory solid tumors. Cancer Chemother Pharmacol 2019;83:1025-35.

94. Sinn M, Liersch T, Riess H, et al. CONKO-006: A randomised double-blinded phase IIb-study of additive therapy with gemcitabine + sorafenib/placebo in patients with R1 resection of pancreatic cancer - Final results. Eur J Cancer 2020;138:172-81.

95. Wei AC, Ou FS, Shi Q, et al. Perioperative Gemcitabine+Erlotinib Plus Pancreaticoduodenectomy for Resectable Pancreatic Adenocarcinoma: ACOSOG Z5041 (Alliance) Phase II Trial. Ann Surg Oncol 2019;26:4489-97.

96. Maurel J, Sánchez-Cabús S, Laquente B, et al. Outcomes after neoadjuvant treatment with gemcitabine and erlotinib followed by gemcitabine-erlotinib and radiotherapy for resectable pancreatic cancer (GEMCAD 10-03 trial). Cancer Chemother Pharmacol 2018;82:935-43.

97. Fuchs CS, Azevedo S, Okusaka T, et al. A phase 3 randomized, double-blind, placebo-controlled trial of ganitumab or placebo in combination with gemcitabine as first-line therapy for metastatic adenocarcinoma of the pancreas: the GAMMA trial. Ann Oncol 2015;26:921-7.

98. Chung V, McDonough S, Philip PA, et al. Effect of Selumetinib and MK-2206 vs Oxaliplatin and Fluorouracil in Patients With Metastatic Pancreatic Cancer After Prior Therapy: SWOG S1115 Study Randomized Clinical Trial. JAMA Oncol 2017;3:516-22.

99. Tempero M, Oh DY, Tabernero J, et al. Ibrutinib in combination with nab-paclitaxel and gemcitabine for first-line treatment of patients with metastatic pancreatic adenocarcinoma: phase III RESOLVE study. Ann Oncol 2021;32:600-8.

100.Hu ZI, Bendell JC, Bullock A, et al. A randomized phase II trial of nab-paclitaxel and gemcitabine with tarextumab or placebo in patients with untreated metastatic pancreatic cancer. Cancer Med 2019;8:5148-57.

101. Bendell J, Sharma S, Patel MR, et al. Safety and Efficacy of Andecaliximab (GS-5745) Plus Gemcitabine and Nab-Paclitaxel in Patients with Advanced Pancreatic Adenocarcinoma: Results from a Phase I Study. Oncologist 2020;25:954-62.

102. Davis SL, Cardin DB, Shahda S, et al. A phase $1 \mathrm{~b}$ dose escalation study of Wnt pathway inhibitor vantictumab in combination with nab-paclitaxel and gemcitabine in patients with previously untreated metastatic pancreatic cancer. Invest New Drugs 2020;38:821-30.

103. Royal RE, Levy C, Turner K, et al. Phase 2 trial of single agent Ipilimumab (anti-CTLA-4) for locally advanced or metastatic pancreatic adenocarcinoma. J Immunother 2010;33:828-33.

104. Beatty GL, Chiorean EG, Fishman MP, et al. CD40 agonists alter tumor stroma and show efficacy against pancreatic carcinoma in mice and humans. Science 2011;331:1612-6.

105. Brahmer JR, Tykodi SS, Chow LQ, et al. Safety and activity of anti-PD-L1 antibody in patients with advanced cancer. N Engl J Med 2012;366:2455-65.

106.Le DT, Lutz E, Uram JN, et al. Evaluation of ipilimumab in combination with allogeneic pancreatic tumor cells transfected with a GM-CSF gene in previously treated pancreatic cancer. J Immunother 2013;36:382-9.

107.Aglietta M, Barone C, Sawyer MB, et al. A phase I dose escalation trial of tremelimumab (CP-675,206) in combination with gemcitabine in chemotherapy-naive patients with metastatic pancreatic cancer. Ann Oncol 2014;25:1750-5.

108. Kalyan A, Kircher S, Mohindra NA, et al. Ipilimumab 
and gemcitabine for advanced pancreas cancer: A phase Ib study. J Clin Oncol 2016;34:e15747.

109. Duffy AG, Makarova-Rusher OV, Kleiner DE, et al. A pilot study of immune checkpoint inhibition in combination with radiation therapy in patients with metastatic pancreatic cancer. J Clin Oncol 2017;35:15 Suppl:e15786.

110. Katz MHG, Varadhachary RG, Bauer TW, et al. Preliminary safety data from a randomized multicenter phase Ib/II study of neoadjuvant chemoradiation therapy (CRT) alone or in combination with pembrolizumab in patients with resectable or borderline resectable pancreatic cancer. J Clin Oncol 2017;35:4125.

111. Yamamoto N, Muro K, Ishii H, et al. Anti-CC-chemokine receptor 4 (CCR4) antibody mogamulizumab (Moga) and nivolumab (Nivo) combination phase I study in patients with advanced or metastatic solid tumors. Ann Oncol 2017;28: Suppl 5:611.

112. Cavalieri CC, Swason E, Whisenant JR, et al. Pembroliuzmab in gastrointestinal (GI) malignancies with defective DNA mismatch repair (dMMR): A single institution experience. J Clin Oncol 2017;35:4 suppl:792.

113. O'Reilly EM, Oh DY, Dhani N, et al. Durvalumab With or Without Tremelimumab for Patients With Metastatic Pancreatic Ductal Adenocarcinoma: A Phase 2 Randomized Clinical Trial. JAMA Oncol 2019;5:1431-8.

114. Naing A, Powderly JD, Falchook G, et al. Epacadostat plus durvalumab in patients with advanced solid tumors: preliminary results of the ongoing, open-label, phase I/II ECHO-203 study. Cancer Res 2018;78:CT177.

115. Weiss GJ, Blaydorn L, Beck J, et al. Phase Ib/II study of gemcitabine, nab-paclitaxel, and pembrolizumab in metastatic pancreatic adenocarcinoma. Invest New Drugs 2018;36:96-102.

116. Borazanci EH, Jameson GS, Borad MJ, et al. A phase II pilot trial of nivolumab $(\mathrm{N})+$ albumin bound paclitaxel $(\mathrm{AP})+$ paricalcitol $(\mathrm{P})+$ cisplatin $(\mathrm{C})+$ gemcitabine (G) (NAPPCG) in patients with previously untreated metastatic pancreatic ductal adenocarcinoma (PDAC). J Clin Oncol 2018;36:4 suppl:358.

117.Hu ZI, Hellmann MD, Wolchok JD, et al. Acquired resistance to immunotherapy in MMR-D pancreatic cancer. J Immunother Cancer 2018;6:127.

118. Wainberg ZA, Hochster HS, Jae-Hoon Kim E, et al. Phase I study of nivolumab (Nivo) + nab-paclitaxel (nab-P) + gemcitabine (Gem) in advanced pancreatic cancer (APC). J Clin Oncol 2019;37:4 suppl:298.

119.Hong D, Rasco D, Veeder M, et al. A Phase 1b/2 Study of the Bruton Tyrosine Kinase Inhibitor Ibrutinib and the
PD-L1 Inhibitor Durvalumab in Patients with Pretreated Solid Tumors. Oncology 2019;97:102-11.

120. Doi T, Muro K, Ishii H, et al. A Phase I Study of the AntiCC Chemokine Receptor 4 Antibody, Mogamulizumab, in Combination with Nivolumab in Patients with Advanced or Metastatic Solid Tumors. Clin Cancer Res 2019;25:6614-22.

121. Kamath SD, Kalyan A, Kircher S, et al. Ipilimumab and Gemcitabine for Advanced Pancreatic Cancer: A Phase Ib Study. Oncologist 2020;25:e808-15.

122.Mahalingam D, Wilkinson GA, Eng KH, et al. Pembrolizumab in Combination with the Oncolytic Virus Pelareorep and Chemotherapy in Patients with Advanced Pancreatic Adenocarcinoma: A Phase Ib Study. Clin Cancer Res 2020;26:71-81.

123. Overman M, Javle M, Davis RE, et al. Randomized phase II study of the Bruton tyrosine kinase inhibitor acalabrutinib, alone or with pembrolizumab in patients with advanced pancreatic cancer. J Immunother Cancer 2020;8:e000587.

124. O'Neill C, Hayat T, Hamm J, et al. A phase 1b trial of concurrent immunotherapy and irreversible electroporation in the treatment of locally advanced pancreatic adenocarcinoma. Surgery 2020;168:610-6.

125. Fumet JD, Limagne E, Thibaudin M, et al. Precision medicine phase II study evaluating the efficacy of a double immunotherapy by durvalumab and tremelimumab combined with olaparib in patients with solid cancers and carriers of homologous recombination repair genes mutation in response or stable after olaparib treatment. BMC Cancer 2020;20:748.

126. Renouf DJ, Knox JJ, Kavan P, et al. The Canadian Cancer Trials Group PA.7 trial: Results of a randomized phase II study of gemcitabine (GEM) and nab-paclitaxel (Nab-P) vs GEM, nab-P, durvalumab (D) and tremelimumab (T) as first line therapy in metastatic pancreatic ductal adenocarcinoma (mPDAC). Ann Oncol 2020;31:4 suppl: S1195:s1142-215.

127. O'Hara MH, O'Reilly EM, Varadhachary G, et al. CD40 agonistic monoclonal antibody APX005M (sotigalimab) and chemotherapy, with or without nivolumab, for the treatment of metastatic pancreatic adenocarcinoma: an open-label, multicentre, phase $1 \mathrm{~b}$ study. Lancet Oncol 2021;22:118-31.

128.Zhu X, Cao Y, Liu W, et al. Stereotactic body radiotherapy plus pembrolizumab and trametinib versus stereotactic body radiotherapy plus gemcitabine for locally recurrent pancreatic cancer after surgical resection: an open-label, 
randomised, controlled, phase 2 trial. Lancet Oncol 2021;22:1093-102.

129. Le DT, Durham JN, Smith KN, et al. Mismatch repair deficiency predicts response of solid tumors to PD-1 blockade. Science 2017;357:409-13.

130.Pecher G, Häring A, Kaiser L, et al. Mucin gene (MUC1) transfected dendritic cells as vaccine: results of a phase I/II clinical trial. Cancer Immunol Immunother 2002;51:669-73.

131. Mazzolini G, Alfaro C, Sangro B, et al. Intratumoral injection of dendritic cells engineered to secrete interleukin-12 by recombinant adenovirus in patients with metastatic gastrointestinal carcinomas. J Clin Oncol 2005;23:999-1010.

132. Lepisto AJ, Moser AJ, Zeh H, et al. A phase I/II study of a MUC1 peptide pulsed autologous dendritic cell vaccine as adjuvant therapy in patients with resected pancreatic and biliary tumors. Cancer Ther 2008;6:955-64.

133. Nakamura M, Wada J, Suzuki H, et al. Long-term outcome of immunotherapy for patients with refractory pancreatic cancer. Anticancer Res 2009;29:831-6.

134. Hirooka Y, Itoh A, Kawashima H, et al. A combination therapy of gemcitabine with immunotherapy for patients with inoperable locally advanced pancreatic cancer. Pancreas 2009;38:e69-74.

135.Suso EM, Dueland S, Rasmussen AM, et al. hTERT mRNA dendritic cell vaccination: complete response in a pancreatic cancer patient associated with response against several hTERT epitopes. Cancer Immunol Immunother 2011;60:809-18.

136. Rong Y, Qin X, Jin D, et al. A phase I pilot trial of MUC1peptide-pulsed dendritic cells in the treatment of advanced pancreatic cancer. Clin Exp Med 2012;12:173-80.

137.Kimura Y, Tsukada J, Tomoda T, et al. Clinical and immunologic evaluation of dendritic cell-based immunotherapy in combination with gemcitabine and/ or S-1 in patients with advanced pancreatic carcinoma. Pancreas 2012;41:195-205.

138. Qiu Y, Yun MM, Xu MB, et al. Pancreatic carcinomaspecific immunotherapy using synthesised alpha-galactosyl epitope-activated immune responders: findings from a pilot study. Int J Clin Oncol 2013;18:657-65.

139. Koido S, Homma S, Okamoto M, et al. Treatment with chemotherapy and dendritic cells pulsed with multiple Wilms' tumor 1 (W'T1)-specific MHC class I/IIrestricted epitopes for pancreatic cancer. Clin Cancer Res 2014;20:4228-39.

140. Mayanagi S, Kitago M, Sakurai T, et al. Phase I pilot study of Wilms tumor gene 1 peptide-pulsed dendritic cell vaccination combined with gemcitabine in pancreatic cancer. Cancer Sci 2015;106:397-406.

141. Mehrotra S, Britten CD, Chin S, et al. Vaccination with poly(IC:LC) and peptide-pulsed autologous dendritic cells in patients with pancreatic cancer. J Hematol Oncol 2017;10:82.

142.Jiang N, Qiao G, Wang X, et al. Dendritic Cell/CytokineInduced Killer Cell Immunotherapy Combined with S-1 in Patients with Advanced Pancreatic Cancer: A Prospective Study. Clin Cancer Res 2017;23:5066-73.

143. Yanagisawa R, Koizumi T, Koya T, et al. WT1-pulsed Dendritic Cell Vaccine Combined with Chemotherapy for Resected Pancreatic Cancer in a Phase I Study. Anticancer Res 2018;38:2217-25.

144. Rosenberg SA, Dudley ME. Adoptive cell therapy for the treatment of patients with metastatic melanoma. Curr Opin Immunol 2009;21:233-40.

145. Dafni U, Michielin O, Lluesma SM, et al. Efficacy of adoptive therapy with tumor-infiltrating lymphocytes and recombinant interleukin-2 in advanced cutaneous melanoma: a systematic review and meta-analysis. Ann Oncol 2019;30:1902-13.

146. Dudley ME, Wunderlich JR, Yang JC, et al. Adoptive cell transfer therapy following non-myeloablative but lymphodepleting chemotherapy for the treatment of patients with refractory metastatic melanoma. J Clin Oncol 2005;23:2346-57.

147. Goff SL, Dudley ME, Citrin DE, et al. Randomized, Prospective Evaluation Comparing Intensity of Lymphodepletion Before Adoptive Transfer of TumorInfiltrating Lymphocytes for Patients With Metastatic Melanoma. J Clin Oncol 2016;34:2389-97.

148. Meng Q, Liu Z, Rangelova E, et al. Expansion of Tumorreactive T Cells From Patients With Pancreatic Cancer. J Immunother 2016;39:81-9.

149. Hall M, Liu H, Malafa M, et al. Expansion of tumorinfiltrating lymphocytes (TIL) from human pancreatic tumors. J Immunother Cancer 2016;4:61.

150. (NCI) NCI. ClinicalTrials.gov. Available online: https:// clinicaltrials.gov/ct2/show/NCT01174121?id=NCT01174 $121 \&$ draw $=2 \&$ rank=1\&load $=$ cart

151. Amaria RN, Bernatchez C, Forget M, et al. Adoptive transfer of tumor-infiltrating lymphocytes in patients with sarcomas, ovarian, and pancreatic cancers. J Clin Oncol 2019;37:abstr TPS2650.

152.Kawaoka T, Oka M, Takashima M, et al. Adoptive immunotherapy for pancreatic cancer: cytotoxic $\mathrm{T}$ 
lymphocytes stimulated by the MUC1-expressing human pancreatic cancer cell line YPK-1. Oncol Rep 2008;20:155-63.

153. Kondo H, Hazama S, Kawaoka T, et al. Adoptive immunotherapy for pancreatic cancer using MUC1 peptide-pulsed dendritic cells and activated T lymphocytes. Anticancer Res 2008;28:379-87.

154. Chung MJ, Park JY, Bang S, et al. Phase II clinical trial of ex vivo-expanded cytokine-induced killer cells therapy in advanced pancreatic cancer. Cancer Immunol Immunother 2014;63:939-46.

155.Aoki T, Matsushita H, Hoshikawa M, et al. Adjuvant combination therapy with gemcitabine and autologous $\gamma \delta$ T-cell transfer in patients with curatively resected pancreatic cancer. Cytotherapy 2017;19:473-85.

156. Lin M, Liang S, Wang X, et al. Percutaneous irreversible electroporation combined with allogeneic natural killer cell immunotherapy for patients with unresectable (stage III/IV) pancreatic cancer: a promising treatment. J Cancer Res Clin Oncol 2017;143:2607-18.

157. Beatty GL, O'Hara MH, Lacey SF, et al. Activity of Mesothelin-Specific Chimeric Antigen Receptor T Cells Against Pancreatic Carcinoma Metastases in a Phase 1 Trial. Gastroenterology 2018;155:29-32.

158. Omazic B, Ayoglu B, Löhr M, et al. A Preliminary

Cite this article as: Rangelova E, Kaipe H. Immunotherapy in pancreatic cancer-an emerging role: a narrative review. Chin Clin Oncol 2022;11(1):4. doi: 10.21037/cco-21-174
Report: Radical Surgery and Stem Cell Transplantation for the Treatment of Patients With Pancreatic Cancer. J Immunother 2017;40:132-9.

159. Kubo T, Tsurita G, Hirohashi Y, et al. Immunohistological analysis of pancreatic carcinoma after vaccination with survivin 2B peptide: Analysis of an autopsy series. Cancer Sci 2019;110:2386-95.

160. Dudley ME, Gross CA, Langhan MM, et al. CD8+ enriched "young" tumor infiltrating lymphocytes can mediate regression of metastatic melanoma. Clin Cancer Res 2010;16:6122-31.

161.Itzhaki O, Hovav E, Ziporen Y, et al. Establishment and large-scale expansion of minimally cultured "young" tumor infiltrating lymphocytes for adoptive transfer therapy. J Immunother 2011;34:212-20.

162. Besser MJ, Shapira-Frommer R, Treves AJ, et al. Minimally cultured or selected autologous tumorinfiltrating lymphocytes after a lympho-depleting chemotherapy regimen in metastatic melanoma patients. J Immunother 2009;32:415-23.

163. Pishvaian M, Morse MA, McDevitt J, et al. Phase 1 Dose Escalation Study of MEDI-565, a Bispecific T-Cell Engager that Targets Human Carcinoembryonic Antigen, in Patients With Advanced Gastrointestinal Adenocarcinomas. Clin Colorectal Cancer 2016;15:345-51. 
Table S1 Antibody trials in pancreatic cance

\begin{tabular}{|c|c|c|c|c|c|c|c|c|c|c|}
\hline Trial (year) & Phase & \#pts & Target & Agent & Stage & 1st/2nd line & Other Tx & Median OS & Result & Comment \\
\hline Xiong (2004)(86) & ॥ & 41 & EGFR & Cetuximab & LAPC, M1 & $1^{\text {st }}$ & Gem & $7.1 \mathrm{mo}$ & $\begin{array}{l}1 \text {-year OS 31\% } \\
\text { PR } 12 \%, \text { SD 63\% }\end{array}$ & intratumoral EGFR expression \\
\hline Van Cutsem (2009)(87) & III RCT & 607 & $\begin{array}{l}\text { EGFR, } \\
\text { VEGF-A }\end{array}$ & $\begin{array}{c}\text { Erlotinib } \\
+ \text { Bevacizumab }\end{array}$ & M1 & $1^{\text {st }}$ & Gem & 7.1 vs. $6 \mathrm{mo}$ & No benefit & $\begin{array}{l}\text { 1.Gem+Erl+Bev } \\
\text { 2.Gem+Erl+placebo }\end{array}$ \\
\hline Fuchs (2015)(97) & III RCT & 800 & IGF1R & Ganitumab & M1 & $1^{\text {th }}$ & Gem & $\begin{array}{l}7.0 \text { vs. } 7.1 \text { vs. } 7.2 \\
\text { mo OS }\end{array}$ & Well tolerated, no improvement of survival & Gem $+12 \mathrm{mg} / \mathrm{kg},+20 \mathrm{mg} / \mathrm{kg}$ vs. +placebo \\
\hline Picozzi (2015)(165) & Ib RCT & 58 & MUC5ac & $\begin{array}{l}{ }^{90} \text { Yttrium- } \\
\text { clivatuzumab } \\
\text { tetraxetan }\end{array}$ & M1 & $3^{\text {rd }}+$ & $+/-\mathrm{Gem}$ & $\begin{array}{l}7.9 \text { vs. } 3.4 \mathrm{mo}^{*} \\
(p=0.004)\end{array}$ & $\begin{array}{l}\text { * for multiple cycles +Gem } \\
\text { OS } 2.7 \text { vs. } 2.6 \text { mo in the whole cohorts }\end{array}$ & $\begin{array}{l}+/ \text { - gemcitabine } \\
\text { Ab with isotope }\end{array}$ \\
\hline Ko (2016)(88) & $\|$ & 46 & $\begin{array}{l}\text { EGFR } \\
\text { MEK1/2 }\end{array}$ & $\begin{array}{l}\text { Erlotinib } \\
\text { Selumetinib }\end{array}$ & LAPC, M1 & $2^{\text {nd }}$ & no & $7.3 \mathrm{mo}$ & No objective responses. In 38\% SD in $6 \mathrm{w}+$ & $59 \%$ with additional chemotherapy after study's discontinuation \\
\hline Coveler (2016)(166) & 1 & $35 / 50$ & SLC-44A4 & ASG-5ME & M1 & $2^{\text {nd }}+$ & no & $5 \mathrm{mo}$ & Well tolerated, limited tumor activity - $1 \mathrm{PR}$ & $\begin{array}{l}\text { PC + gastric cancer } \\
\text { Ab-drug conjugate against cell-surface target on most PC. \& gastric } \\
\text { cancers }\end{array}$ \\
\hline Beg (2016)(167) & 1 & $4 / 19$ & MUC5AC & NEO-102 & LAPC, M1 & $2^{\text {nd }}+$ & no & $\mathrm{nr}$ & Well tolerated, no objective responses & PC and colon cancer \\
\hline Pishvaian (2016)(163) & 1 & $6 / 39$ & $\begin{array}{l}\text { CEA \& CD3 epsilon } \\
\text { TCR subunit }\end{array}$ & MEDI-565 & $\mathrm{nr}$ & $2^{\text {nd }}+$ & no & $\mathrm{nr}$ & No objective responses. $28 \%$ of all cancer SD at best & $\begin{array}{l}\text { Gl tumors: Bispecific Ab } \\
\text { Pretreated with dexamethasone }\end{array}$ \\
\hline Chung (2017)(98) & ॥ RCT & 137 & $\begin{array}{c}\text { MEK } \\
\text { PI3K/AKT }\end{array}$ & $\begin{array}{l}\text { Selumetinib } \\
\text { MK-2206 }\end{array}$ & M1 & $2^{\text {nd }}$ & no & 3.9 vs. $6.7 \mathrm{mo}$ & Shorter survival with immunotherapy & vs. oxaliplatin and fluorouracil (FOLFOX) \\
\hline Almhanna (2017)(169) & $\|$ & 43 & Guanylyl cyclase & MLN0264 & LAPC, M1 & $2^{\text {nd }}+$ & no & $5.4 \mathrm{mo}$ & Managable safety but low efficacy, response rate $3 \%$ & Ab-drug conjugate \\
\hline Fountzilas (2017)(89) & $\|$ & 18 & EGFR & Erlotinib & LAPC, M1 & $1^{\text {st }}, 2^{\text {nd }}$ & no & $3 \mathrm{mo}$ & Terminated early due to futility & \\
\hline Cardin (2018)(170) & 1 & 19 & $\begin{array}{c}\text { Src } \\
\text { EGFR }\end{array}$ & $\begin{array}{l}\text { Dasatinib } \\
\text { Erlotinib }\end{array}$ & LAPC, M1 & $1^{\text {st }}$ & Gem & $8 \mathrm{mo}$ & No objective responses. 9 pts had SD & 1 -y survival $32 \%$ \\
\hline Abdel-Wahab (2018)(90) & I/II RCT & 45 & $\begin{array}{l}\text { IGF-1R } \\
\text { EGFR }\end{array}$ & $\begin{array}{c}\text { MK-0646 } \\
\text { Erlotinib }\end{array}$ & M1 & $1^{\text {st }}$ & Gem & $\begin{array}{l}10.4 \text { (A) vs. } \\
5.7 \mathrm{mo}(\mathrm{C})\end{array}$ & Best survival in MK arm, no additional benefit of Erlotinib. Low toxicity & 3 arms $-A: G e m+M K, B: G e m+M K+E$ or $C: G e m+E$ \\
\hline Maurel (2018)(96) & ॥ & 25 & EGFR & Erlotinib & resected & NAT & Gem+RT & $23.8 \mathrm{mo}$ & $\begin{array}{l}\text { Better OS for R0 vs. R1 resection or not resected: } 65.5 \text { mo vs.. } 15.5 \text { mo, } \\
P=0.01\end{array}$ & \\
\hline Dittrich (2019)(171) & Ib & 30 & $\begin{array}{l}\text { EGFR } \\
\text { VEGF }\end{array}$ & $\begin{array}{l}\text { Erlotinib } \\
\text { Bevacisumab }\end{array}$ & LAPC, M1 & $1^{1 \mathrm{t}}$ in $\mathrm{M} 1$ & Cap & $2.5 \mathrm{mo}$ PFS & Good safety, but limited efficacy. & $2 \mathrm{PR}, 8 / 28 \mathrm{SD}$ at $6 \mathrm{mo}$ \\
\hline Halfdanarson (2019)(92) & II RCT & 92 & EGFR & $\begin{array}{l}\text { Panitumumab, } \\
\text { Erlotinib }\end{array}$ & M1 & $1^{\text {st }}$ & Gem & $\begin{array}{l}4.2 \mathrm{vs} \\
8.3 \mathrm{mo} \text { os }\end{array}$ & Longer OS with dual inhibition, but increased toxicity & Gem $+E$ vs. Gem+E+P \\
\hline Mettu (2019)(93) & 1 & 21 & $\begin{array}{l}\text { Src, } \\
\text { EGFR }\end{array}$ & $\begin{array}{l}\text { Dasatinib, } \\
\text { Cetuximab }\end{array}$ & LAPC, M1 & $2^{\text {nd }}+$ & Gem & $5.8 \mathrm{mo}$ & Limited clinical effect, but toxicity with both & $\begin{array}{l}\text { Solid tumors } \\
\text { Gem + Das or Gem + Das/Cet }\end{array}$ \\
\hline Davis (2020)(102) & Ib & 31 & Wnt pathway & Vantictumab & M1 & $1^{\text {st }}$ & GnP & $10 \mathrm{mo}$ & $42 \% \mathrm{PR}$ and $35.5 \% \mathrm{SD}$ & $\begin{array}{l}\text { Terminated due to pathologic-fracture related safety, Max tolerated dose } \\
\text { not reached }\end{array}$ \\
\hline Hu (2019)(100) & II RCT & 177 & Notch2/3R & Tarextumab & M1 & $1^{\text {st }}$ & GnP & 6.4 vs. $7.9 \mathrm{mo}$ & No diff in $\mathrm{OS}$, even somewhat better in the placebo $(\mathrm{p}=0.9)$ & \\
\hline Wei (2019)(95) & $\|$ & 114 & EGFR & Erlotinib & Resected, head & $N A T+A d j$ & Gem & $\begin{array}{l}21.3 \mathrm{mo} \\
25.4 \mathrm{mo} \text { for } \\
\text { resected }\end{array}$ & Feasible & $83 / 114$ resected. $52 \%$ 2-year survival for resected \\
\hline Alewine (2020)(173) & $1 / 11$ & 20 & mesothelin & $\begin{array}{l}\text { LMB-100 } \\
\text { (immunotoxin) } \\
\text { + modified } \\
\text { Pseudomonas } \\
\text { exotoxin A }\end{array}$ & $\begin{array}{c}\text { Advanced, } \\
\text { recurrent }\end{array}$ & $2^{\text {nd }}+$ & $\mathrm{nPac}$ & $\mathrm{nr}$ & $\begin{array}{l}1 \mathrm{PR}, 7>50 \% \text { decrease of CA19-9. } \\
\text { Not well tolerated }\end{array}$ & $\begin{array}{l}\text { Ab+exotoxin } \\
\text { Higher mesothelin expression in pts with tumor marker responses }\end{array}$ \\
\hline Bendell (2020)(101) & 1 & 36 & MMP9 & Andecaliximab & LAPC, M1 & $1^{\text {st }}$ (in M1) & $\mathrm{GnP}+\mathrm{Ab}$ & $7.8 \mathrm{mo}$ PFS & Well tolerated; PR in 44\% (RECIST) & 1st line in the metastatic setting \\
\hline $\operatorname{Sinn}(2020)(94)$ & IIIb RCT & 122 & $\begin{array}{l}\text { VEGFR, PDGFR, } \\
\text { RAF, etc }\end{array}$ & Sorafenib & Resected R1 & $1^{\text {st }}$ & Gem & $\begin{array}{c}17.6 \mathrm{mo} \mathrm{vs} . \\
17.5 \mathrm{mo}\end{array}$ & No diff in RFS no OS & Gem + Ab's vs. Gem + placebo \\
\hline Assenat (2021)(174) & ॥ & 63 & $\begin{array}{l}\text { HER2, } \\
\text { EGFR }\end{array}$ & $\begin{array}{c}\text { Trastusumab + } \\
\text { Erlotinib }\end{array}$ & M1 & $1^{\text {st }}$ & $\mathrm{Gem}+\mathrm{Ab}$ & OS $7.9 \mathrm{mo}$ & No control group & $\begin{array}{l}\text { PFS better when grade }>=2 \text { cutaneous toxicity; HER2 and EGFR } \\
\text { expression corr with survival on multivariate analysis }\end{array}$ \\
\hline Tempero (2021)(99) & III RCT & 424 & BTK & Ibrutinib & M1 & $1^{\text {th }}$ & $\begin{array}{l}\text { GnP+Ab vs. } \\
\text { GnP + placebo }\end{array}$ & $\begin{array}{l}9.7 \mathrm{mo} \mathrm{vs} \\
10.8 \mathrm{mo}\end{array}$ & No diff in OS & More side effects and receiving lower dose chemo with $\mathrm{Ab}$ \\
\hline Lim (2021)(91) & II RCT & 65 & EGFR & Erlotinib & LAPC, M1 & $1^{\text {st }}$ & $\begin{array}{c}\text { GemOx }+E \\
\text { versus Gem +E }\end{array}$ & $\begin{array}{l}3.9 \text { mo vs. } \\
=1.4 \mathrm{mo} \mathrm{PFS}, \mathrm{not} \\
\text { OS (trend) }\end{array}$ & Better PFS with oxaliplatin, & Ab not tested - Erlotinib in both chemo arms, so unknown benefit \\
\hline
\end{tabular}




\section{References}

164. Fujisaka Y, Kurata T, Tanaka K, et al. Phase I study of amatuximab, a novel monoclonal antibody to mesothelin, in Japanese patients with advanced solid tumors. Invest New Drugs 2015;33:380-8.

165.Picozzi VJ, Ramanathan RK, Lowery MA, et al. (90) Y-clivatuzumab tetraxetan with or without low-dose gemcitabine: A phase Ib study in patients with metastatic pancreatic cancer after two or more prior therapies. Eur J Cancer 2015;51:1857-64.

166. Coveler AL, Ko AH, Catenacci DV, et al. A phase 1 clinical trial of ASG-5ME, a novel drug-antibody conjugate targeting SLC44A4, in patients with advanced pancreatic and gastric cancers. Invest New Drugs 2016;34:319-28.

167. Beg MS, Azad NS, Patel SP, et al. A phase 1 doseescalation study of NEO-102 in patients with refractory colon and pancreatic cancer. Cancer Chemother Pharmacol 2016;78:577-84.

168. Benson AB 3rd, Wainberg ZA, Hecht JR, et al. A Phase II Randomized, Double-Blind, Placebo-Controlled Study of Simtuzumab or Placebo in Combination with Gemcitabine for the First-Line Treatment of Pancreatic Adenocarcinoma. Oncologist 2017;22:241-e15.

169.Almhanna K, Wright D, Mercade TM, et al. A phase II study of antibody-drug conjugate, TAK-264 (MLN0264) in previously treated patients with advanced or metastatic pancreatic adenocarcinoma expressing guanylyl cyclase C. Invest New Drugs 2017;35:634-41.

170. Cardin DB, Goff LW, Chan E, et al. Dual Src and EGFR inhibition in combination with gemcitabine in advanced pancreatic cancer: phase I results: A phase I clinical trial. Invest New Drugs 2018;36:442-50.

171.Dittrich C, Königsberg R, Mittlböck M, et al. Phase Ib trial combining capecitabine, erlotinib and bevacizumab in pancreatic adenocarcinoma - REBECA trial. Invest New Drugs 2019;37:127-38.

172. Lin C, Verma V, Ly QP, et al. Phase I trial of concurrent stereotactic body radiotherapy and nelfinavir for locally advanced borderline or unresectable pancreatic adenocarcinoma. Radiother Oncol 2019;132:55-62.

173. Alewine C, Ahmad M, Peer CJ, et al. Phase I/II Study of the Mesothelin-targeted Immunotoxin LMB-100 with Nab-Paclitaxel for Patients with Advanced Pancreatic Adenocarcinoma. Clin Cancer Res 2020;26:828-36.

174. Assenat E, Mineur L, Mollevi C, et al. Phase II study evaluating the association of gemcitabine, trastuzumab and erlotinib as first-line treatment in patients with metastatic pancreatic adenocarcinoma (GATE 1). Int J Cancer 2021;148:682-91. 